Yeshiva University, Cardozo School of Law

LARC @ Cardozo Law

Articles

Faculty

2017

\title{
Fashion's Function in Intellectual Property Law
}

Christopher Buccafusco

Benjamin N. Cardozo School of Law, christopher.buccafusco@yu.edu

Jeanne C. Fromer

Follow this and additional works at: https://larc.cardozo.yu.edu/faculty-articles

Part of the Law Commons

\section{Recommended Citation}

Christopher Buccafusco \& Jeanne C. Fromer, Fashion's Function in Intellectual Property Law, 93 Notre Dame Law Review 51 (2017).

Available at: https://larc.cardozo.yu.edu/faculty-articles/473

This Article is brought to you for free and open access by the Faculty at LARC @ Cardozo Law. It has been accepted for inclusion in Articles by an authorized administrator of LARC @ Cardozo Law. For more information, please contact larc@yu.edu. 


\title{
FASHION'S FUNCTION IN INTELLEGTUAL
}

\section{PROPERTY LAW}

\author{
Christopher Buccafusco * E Jeanne C. Fromer**
}

Clothing designs can be beautiful. But they are also functional. Fashion's dual nature sits uneasily in intellectual property law, and its treatment by copyright, trademark, and design patent laws has often been perplexing. Much of this difficulty arises from an unclear understanding of the nature of functionality in fashion design. This Article proposes a robust account of fashion's function. It argues that aspects of garment designs are functional not only when they affect the physical or technological performance of a garment but also when they affect the perception of the wearer's body. Generally, clothes are not designed or chosen simply to look good. They are also characteristically designed or chosen to look good on. This approach clarifies the appropriate treatment of fashion design in intellectual property, and it exposes the conceptual limitations of the Supreme Court's recent copyright decision in Star Athletica, L.L.C. v. Varsity Brands, Inc.

(C) 2017 Christopher Buccafusco \& Jeanne C. Fromer. Individuals and nonprofit institutions may reproduce and distribute copies of this Article in any format at or below cost, for educational purposes, so long as each copy identifies the author, provides a citation to the Notre Dame Law Review, and includes this provision in the copyright notice.

* Professor of Law, Director of the Intellectual Property and Information Law Program, Benjamin N. Cardozo School of Law, Yeshiva University.

** Professor of Law, New York University School of Law; Co-Director, Engelberg Center on Innovation Law \& Policy. This Article is the basis for an amicus brief filed by the authors in a recent U.S. Supreme Court case on the copyrightability of cheerleading uniform designs. See Brief of Professors Christopher Buccafusco and Jeanne Fromer as Amici Curiae in Support of Petitioner, Star Athletica, L.L.C. v. Varsity Brands, Inc., 137 S. Ct. 1002 (2017) (No. 15-866), 2016 WL 3971299. The brief benefited greatly from the counsel of Meir Feder and Matthew J. Silveira. The authors are grateful to Amy Adler, Arnaud Ajdler, Barton Beebe, John Bronsteen, Carys Craig, Joseph Fishman, Scott Hemphill, Sonia Katyal, Barbara Kolsun, Mark Lemley, Jonathan Masur, Mark McKenna, Kal Raustiala, Pamela Samuelson, Christopher Sprigman, and Rebecca Tushnet, and participants at the Loyola University Chicago Faculty Workshop, University of Pennsylvania Law School Second Copyright Scholarship Roundtable, and 2017 Works-in-Progress in Intellectual Property Colloquium for their useful and expressive comments. The authors thank Stuart Anello, Mala Chatterjee, Claire Lebé, Giovanna Marchese, and Aleksandra Sitnick for excellent research assistance. Jeanne Fromer also gratefully acknowledges support from the Filomen D'Agostino and Max E. Greenberg Research Fund. A color version of this Article is available at www.ndlawreview.org. 


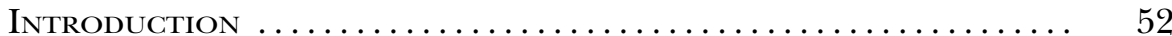

I. How Fashion Design Is Functional ................. 54

II. Fashion's Function in Copyright Law ............... 60

A. The Separate Spheres of Copyright and Patent Laws....... 61

B. Screening Functionality in Pictorial, Graphic, and Sculptural Works .................................... 65

C. The Functionality of Garment Design Features........... 69

1. When Two-Dimensional Designs Are Functional and When They Are Not ................ 76

2. How To Determine Functionality: Experts and Consumers......................... 80

3. Fashion's Function in the Courts ............ 81

D. The Unprotectability of Dual-Nature Design Features in Copyright Law .......................... 83

III. The Conceptual Shortcomings of $S_{\text {tar }}$ Athletica .... 85

IV. Fashion's Function in Trademark Law .............. 93

A. Trademark's Functionality Doctrine $(s) \ldots \ldots \ldots \ldots \ldots \ldots . . \ldots 94$

B. The Functionality of Trademarked Designs That Look Good

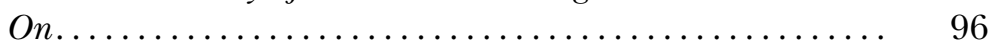

V. Fashion's Function in Design Patent Law ............. 99

A. The Role of Functionality in Design Patent Law.......... 99

B. Patented Designs That Look Good On ............... 103

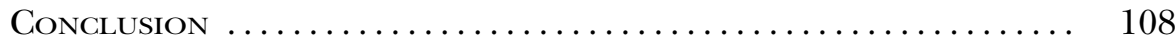

\section{INTRODUCTION}

The creative endeavors of fashion designers have long been celebrated by consumers, journalists, and even museums. But despite the widespread recognition of fashion design's artistry, it has always had an uncertain status within intellectual property law. However beautiful a garment may be, it is also functional. It serves to clothe the body, to keep it warm, and to enable the wearer to perform particular activities while wearing it.

Copyright, trademark, and design patent laws are deeply anxious about protecting functionality. They each use various doctrinal devices to block functional content from their protection, and they channel that content instead toward the utility patent regime. ${ }^{1}$ Take copyright law, for example. Because copyrights are so much easier to obtain and last so much longer than utility patents, allowing designers to protect functional aspects of their works with copyright law would upset utility patent law's careful and different balance between incentives and competition for functional works. If copyright law fails to adequately screen out the functional aspects of garments, competition would thus suffer, as would consumers who would end up paying more for new designs.

1 See infra Section II.A. 
This Article explains how garments function and how different intellectual property regimes should deal with that functionality. Garments are not simply functional to the extent that they serve the mechanical or technological ends of keeping people properly clothed. They are also functional to the extent that they influence the way the wearer is perceived. When aspects of a design affect the perception of the wearer, for example, by making him or her look taller, slimmer, broader, curvier, or lengthier, those aspects of the design must be treated as functional. ${ }^{2}$

The U.S. Supreme Court's recent opinion in Star Athletica, L.L.C. v. Varsity Brands, Inc. ${ }^{3}$ on the copyrightability of cheerleading uniform designs did not recognize this important aspect of the nature of garment design. Because the Supreme Court did not accurately assess the functionality of the cheerleading uniform designs before it, the Court risks conferring a substantial competitive advantage on the designer-plaintiff, one that Congress did not intend to confer ${ }^{4}$ and that the designer did not earn. As we explain here, the contested features of these uniform designs-stripes, chevrons, zigzags, and color-blocking-like many features of fashion design, affect the perception of the wearer by drawing attention to certain aspects of the wearer's body over others and by making the wearer seem to be curvier and have a longer torso.

The account of fashion's functionality that we develop here also has important implications for trademark law and design patent law. Each of these fields also include doctrines that screen out functional features, although in different ways than copyright law does. In this Article, we explain how trademark and design patent laws can more successfully respond to attempts by claimants to protect functional aspects of garment design without satisfying utility patent law's more strenuous demands.

Part I describes our account of fashion's function. We explain how, in addition to technical or mechanical functions, fashion design is also functional when it incorporates features that influence the way the wearer is perceived. Part II explains how copyright law should treat the functional aspects of fashion design in light of copyright law's functionality screening for useful articles, like garment designs, and the law's originality and merger doctrines. In Part III, we illustrate our approach with a case study of the cheerleading uniforms at issue in Star Athletica and demonstrate how the Court went wrong. Parts IV and V, respectively, show how our account of fashion's function should affect trademark and design patent laws.

2 For a related analysis of copyrightability of clothing designs, see Giovanna Marchese, Note, A Tri-Partite Classification Scheme to Clarify Conceptual Separability in the Context of Clothing Design, 38 Cardozo L. Rev. 375 (2016).

3137 S. Ct. 1002 (2017).

4 See Innovative Design Protection Act (IDPA) of 2012, S. 3523, 112th Cong. (2012); Innovative Design Protection and Piracy Prevention Act (IDPPA), H.R. 2511, 112th Cong. (2011). 


\section{How Fashion Design Is Functional}

Copyright, trademark, and design patent laws each limit protection for functional aspects of designs. They each do so in somewhat different ways, as we address in Parts II-IV. Yet these three legal regimes are unified in limiting functional matter as a way to ensure that those design aspects are protected through utility patent law, if at all. ${ }^{5}$ Because of their functionality screens, copyright, trademark, and design patent laws each need to identify the functional aspects of otherwise protectable designs. ${ }^{6}$ This identification task is crucial for fashion designs, which copyright, trademark, and design patent laws might protect, if only in part. This Part analyzes how fashion design is functional.

The features of product designs fall into three mutually exclusive categories. Features can be (1) purely functional; (2) purely nonfunctional; or (3) dual-nature. Consider how these features might appear in different parts of an automobile. The car's spark plugs are rarely seen, and their design may be motivated entirely by utilitarian concerns about size and performance. They would fall into the first category. The sculpture of a leaping jaguar that serves as the car's hood ornament has no functional contribution to the car's operation; it exists merely to look good. It falls into the second, purely nonfunctional, category. Many other aspects of the car's design are simultaneously functional and serve some additional nonfunctional purpose. The shape of the car's hood both makes it look attractive and influences its aerodynamics. The car's wheels may be designed to look speedy, but they must also be able to support the car's weight. These and other features of the car's design are dual-nature.

Knowing what to treat as functional for purposes of garment design requires understanding how clothing can serve utilitarian ends. In some cases this is fairly simple, while in other cases it is more complex. Decisions about the physical or technological performance of a garment should clearly be treated as functional (or at best, "dual nature," that is, serving both functional and expressive ends). ${ }^{7}$ For example, a designer's choices to use fabric that provides warmth even in the coldest temperature or fabric that wicks sweat away from the wearer's body are functional. ${ }^{8}$

5 See infra Parts II-IV.

6 See also Christopher Buccafusco \& Mark A. Lemley, Functionality Screens, 103 VA. L. Rev. 1293 (2017).

7 Cf. Varsity Brands, Inc. v. Star Athletica, LLC, 799 F.3d 468, 490 (6th Cir. 2015) ('Cheerleading uniforms have 'an intrinsic utilitarian function,' namely to 'cover the body, wick away moisture, and withstand the rigors of athletic movements." (quoting Appellants' Brief at 57, Star Athletica, 799 F.3d 468 (No. 14-5237))), aff'd, 137 S. Ct. 1002 (2017).

8 If a designer wants to obtain legal protection for the use of a new kind of performance-enhancing fabric, she needs to apply for a utility patent and prove that her invention is novel and nonobvious. See, e.g., U.S. Patent No. 3,687,754 (filed Apr. 29, 1969) (claiming a "[m] ethod of manufacturing an elastic nonwoven fabric"); U.S. Patent No. 3,563,241 (filed Nov. 14, 1968) ("Water-dispersible nonwoven fabric"); U.S. Patent No. 3,577,607 (filed June 13, 1968) ("Separable fastening fabric"). 
On the other hand, various aspects of garment design could be purely expressive, or aesthetic. A logo for a sports team emblazoned on a t-shirt is one such example. Similarly, a paisley pattern woven into a necktie is probably a purely expressive element of the tie's design. Two-dimensional pictorial or graphic additions to garment designs are the most plausible candidates of these designs for purely expressive elements, although as we show below, the assertion that all two-dimensional elements are nonfunctional is completely incorrect.

Many of a garment's design features will be at least partially functional and fall into the dual-nature category. For example, the incorporation and design of pockets on a pair of trousers may be particularly stylish and visually appealing, but they are also useful because the pockets give the wearer a place for his or her wallet and keys. Thus, the design of pockets and other similar features should also be treated as dual-nature components of garment design. The same might be true for the cut of sleeve that provides a certain degree of warmth, modesty, or ease of movement while simultaneously being beautiful to perceive. Many of the aspects of the fit and cut of a garment fall into the dual-nature category, because although they may look attractive in their own right, they also affect the garment's technical or physical performance as a piece of apparel.

Designs can importantly also function in ways that go beyond standard mechanical or technological utility. In particular, the designs of many garments are intended to and are purchased because they make their wearers look attractive. A designer's choices about hemline, neckline, darting, and, sometimes, fabric prints influence people's perceptions of the wearer. As one design expert puts it, garment design is a unique form of visual art because of the "pervading sense of the human qualities present." 9 A shopper does not simply ask of a garment, "Does it look good?" In addition, and more importantly, he or she asks, "Does it look good on?" and "Does it make me look good?" 10 In this way, the garment's design is valued for what it can do when it is being used. Thus, in addition to the mechanical functions of garment designs, another intrinsic-or essential-function garment designs tend to share is that many of their design features are incorporated to affect the perception of the wearer. ${ }^{11}$

9 Marilyn Revell Delong, The Way We Look: Dress and Aesthetics 134 (2d ed. 1998).

10 See, e.g., J. Fan, Perception of Body Appearance and Its Relation to Clothing, in Clothing Appearance and Fit: Science and Technology 1, 1 (J. Fan et al. eds., 2004) ("Few people have a perfect body. Most people would like to improve their appearance with appropriate clothing, by camouflaging their less desirable attributes and highlighting the more attractive aspects of their bodies.").

11 To be sure, there are some instances of haute couture and other fashion designs that are decidedly not about making the wearer look good. For example, for her spring 1997 showing for Comme des Garçons, Rei Kawakubo-as Vogue described it—"featured tubelike gingham dresses stuffed with lumpen filler that sculpted—some said deformed-a new silhouette.” Spring 1997 Ready-To-Wear: Comme des Garcons, Vogue: Runway (2017), http://www.vogue.com/fashion-shows/spring-1997-ready-to-wear/comme-des-garcons 
Many features of garment design-line, shape, texture, color, and print-exploit features of human visual perception and optical illusions to influence the way in which the wearer's body is perceived. ${ }^{12}$ Importantly, these visual effects can be created with both three-dimensional design techniques such as garment shape and cut as well as with two-dimensional design techniques such as patterns, stripes, and color. Thus, the frequent assertion that two-dimensional fabric design is nonfunctional ${ }^{13}$ is in many cases wrong when the design affects how the wearer is perceived. ${ }^{14}$ Below, we illustrate a number of these techniques, ranging from camouflage to stripe placement.

As all shoppers know, a certain style or cut of a garment may look good on one person but not on another. ${ }^{15}$ And different sorts of designs may affect how people's bodies look. This is not accidental. Design choices create visual effects that can vary the size or shape of the wearer's body or body parts. In this section, we illustrate a number of the most prominent design techniques. Our goal here is not to catalog garment design techniques exhaustively, but rather, by choosing common examples, to illustrate the nature of design functionality.

(last visited Oct. 16, 2017). In such cases, one can still ask whether particular aspects of such fashion design are incorporated to affect the perception of the wearer, as with the unhealthy-looking lumps perceived on the wearers of Kawakubo's gingham dresses. If so, those aspects are just as functional as those that are incorporated to make the wearer look good. Other design aspects of some haute couture and other fashion designs might be purely expressive, with the appearance on the wearer's body being beside the point. Those design aspects are unlikely to be functional in the sense described here.

12 See Marian L. Davis, Visual Design in Dress 21-23, 33 (3d ed. 1996); Delong, supra note 9, at 42, 106-07, 132-33, 166; Marilyn J. Horn \& Lois M. Gurel, The Second Skin 314 (3d ed. 1981).

13 See, e.g., Galiano v. Harrah's Operating Co., 416 F.3d 411, 419 (5th Cir. 2005). For an elaboration of this point, see infra subsection II.C.1.

14 Cf. Brunswick Corp. v. British Seagull Ltd., 35 F.3d 1527 (Fed. Cir. 1994) (holding that the black color of an outboard engine served the utilitarian purpose of making the engine look smaller, and as a result, was undeserving of trademark protection). William Patry, in his treatise, supports the notion that two-dimensional designs are nonfunctional. He asks, "How could it possibly matter whether the design is imprinted on a rug or on a uniform?” 2 William F. Patry, Patry on Copyright \$ 3:151 (2017). As our examples illustrate, however, the placement of two-dimensional designs on a garment can substantially alter how the wearer is perceived. And we strongly suspect that soldiers on the battlefront care, as a protective matter, whether the particular camouflage they are wearing is well matched to their surroundings. Hugo Gye, How U.S. Army Spent $\$ 5$ Billion on 'Failed' Pixel Camouflage. . . Because They 'Wanted to Look Cooler than Marines, 'DAily Mail Online (June 26, 2012), http://www.dailymail.co.uk/news/article-2164686/How-U-S-Army-spent-5BILLION-failed-pixel-camouflage-wanted-look-cooler-Marines.html ("Essentially, the Army designed a universal uniform that universally failed in every environment." (internal quotation marks omitted)).

15 See, e.g., Kat Collings, The Complete Guide to Dressing for Your Body Type, Wно Wнат WeAR (Apr. 27, 2017), http://www.whowhatwear.com/how-to-dress-for-body-type-pearapple-hourglass; Kristin Larson, The Right Clothes for Your Body Type, ReAl Simple, http:// www.realsimple.com/beauty-fashion/clothing/shopping-guide/right-clothes-your-bodytype (last visited Oct. 16, 2016). 
It is common knowledge that the placement of horizontal lines on a garment can make the wearer look shorter and broader, while vertical lines have the opposite effect of lengthening and slimming the wearer's body. ${ }^{16}$ Garment design can visually minimize the size of body parts judged to be too large by either appearing to subdivide those body parts or by counterbalancing them to increase the size of surrounding parts. ${ }^{17}$ For example, a Vshaped neckline can make the neck look longer and narrower while also making shoulder width narrower. ${ }^{18}$ A bodice can be smocked, pleated, draped, or gathered at the bust to make the bust appear larger. ${ }^{19}$ Similarly, as one design textbook indicates, "a line continuing around the body, diagonal stripes that are not too dominant, or a reflecting surface smoothly contouring the body call our attention to the rounded contours." 20

Designers can also affect the perception of the shape of body parts through design choices. Importantly for our purposes, the combination of colors, shapes, and lines can have enormous influence on how the wearer's body is perceived. This is known as color-blocking, and it was recently made famous by Stella McCartney's line of dresses, garment designs employing a color-blocked hourglass appearance that made wearers' bodies look both curvier and slimmer. Two examples of these dresses, as worn by actress Kate Winslet, are shown in Figure 1. The black color along the sides, which changes in width at various points, produces a particularly striking hourglass shape. ${ }^{21}$ And, in the dress on the right, the brighter color on the top of the dress produces a larger and more defined bust. ${ }^{22}$

16 See Davis, supra note 12, at 36-41; Fan, supra note 10, at 11; J. Fan, Psychological Comfort of Fabrics and Garments, in Engineering Apparel Fabrics and Garments 251, 257 tbl.9.1 (J. Fan \& L. Hunter eds., 2009).

17 See Fan, supra note 10 , at 11.

18 DAvis, supra note 12, at 339.

19 Id. at 340.

20 DeLong, supra note 9, at 117.

21 See Saliha Agaç \& Menekse Sakarya, Optical Illusions and Effects on Clothing Design, 3 Int'l J. Sci. Culture \& Sport 137, 154-55 (2015) (discussing this dress design).

$22 I d$. For a related discussion of this dress design and the implications for the copyrightability of fashion designs, see Marchese, supra note 2, at 406-07. 


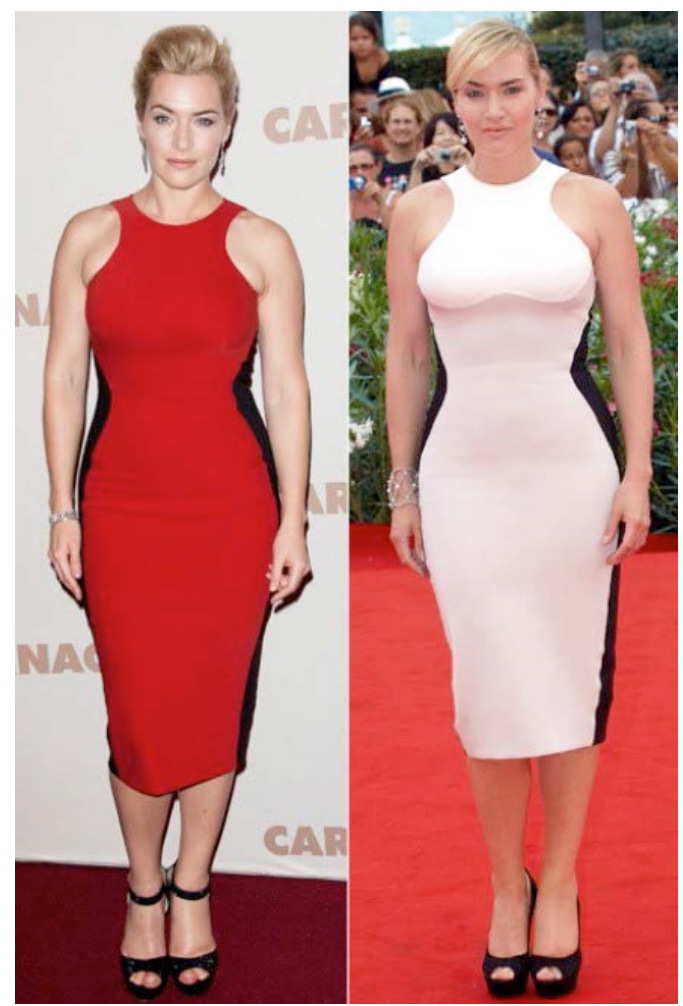

Figure 1: Stella McCartney color-blocked dresses ${ }^{23}$

Optical illusions can also be deployed in garment design to influence perceptions of the wearer's body. ${ }^{24}$ Consider the Müller-Lyer illusion, as shown in Figure 2, which causes a line to look longer if it is bracketed on each end by arrow tails and shorter if it is bracketed on each end by arrow heads. ${ }^{25}$ This illusion can be incorporated into garment designs to lengthen or contract the body of the wearer through placement of arrow tails or heads, respectively, as shown in Figure 3. ${ }^{26}$

23 Fiona Raisbeck, Kate Winslet Wows in Another Body-Con Stella McCartney Dress, MARIE ClaIRE (Nov. 21, 2011), http://www.marieclaire.co.uk/news/fashion/532781/kate-winsletwows-in-another-body-con-stella-mccartney-dress.html\#index $=1$.

24 See generally Davis, supra note 12, at 40-50; Agaç \& Sakarya, supra note 21, at 137 (cataloguing various illusions to be used).

25 See Fan, supra note 16, at 257.

26 See DAvis, supra note 12, at 40; Fan, supra note 16, at 257. 


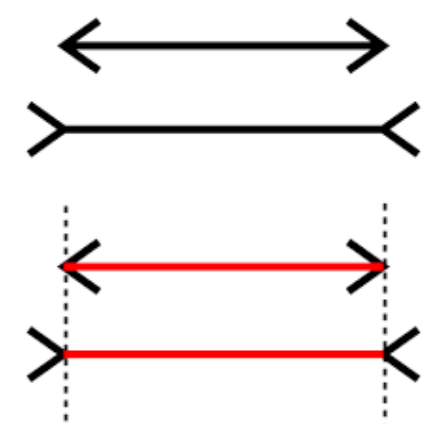

Figure 2: Müller-Lyer Illusion 27
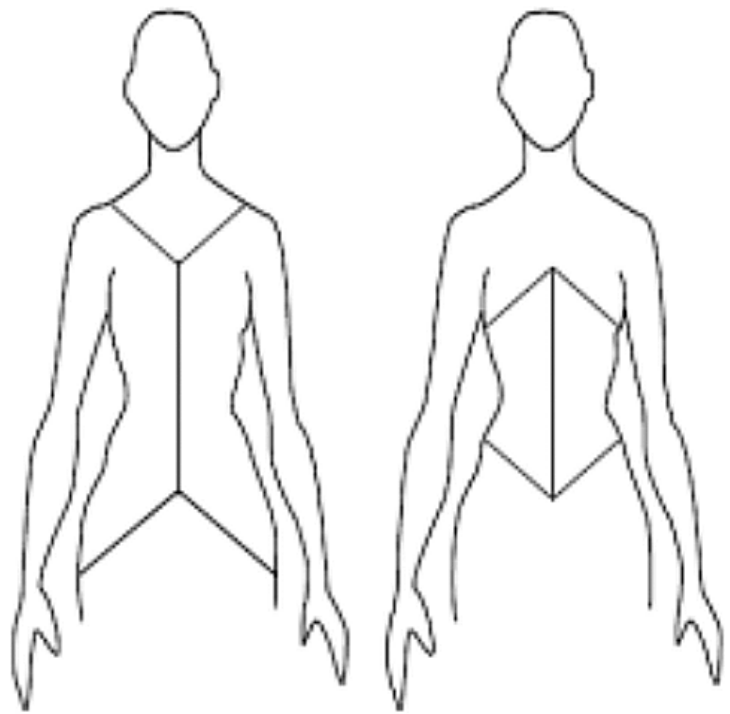

Figure 3: The Müller-Lyer Illusion Applied to Garment Design ${ }^{28}$

To emphasize, or draw attention to, a particular body part, a garment design can include a dominant design element over the body part that it covers when the associated garment is worn. ${ }^{29}$ As two design experts explain more generally, "emphasis can be achieved through strong contrasts in value, but the contrast can also come about through bright intensities of color, unusual shapes, the use of different textures, a boldness of size, or a juxtaposition of contrasting lines." 30 Shapes are good candidates for producing emphasis, especially when large, bold, and contrasted with their surroundings. ${ }^{31}$ Trian-

27 Patric Nordbeck, An Ecological Note on the Müller-Lyer Illusion, PsyPhi > SciFi (Feb. 22, 2015), http://pnpsyphi.blogspot.co.uk/2015/02/an-ecological-note-on-muller-lyer.html.

28 Agaç \& Sakarya, supra note 21, at 143 fig.1.e.

29 DAvis, supra note 12, at 26; Horn \& GUREL, supra note 12, at 320-21.

30 Horn \& Gurel, supra note 12, at 321.

31 See Delong, supra note 9, at 183-84, 189, 244. 
gular shapes or folds in garment design can create visual emphasis by appearing to converge and point at the part of the body covered by these shapes. ${ }^{32}$ The center front area of the body is often chosen for emphasis, drawing attention there and reducing the effect of the volume of the entire body. ${ }^{33}$

These design techniques are not used just because they look attractive on their own. They are used to make the wearer look more attractive. They are part of what make designs inherently work as fashion designs. ${ }^{34}$ By taking advantage of the nature of human vision, these design techniques alter the way we see things in the world. ${ }^{35}$ As two designers explain, "By using art components in this way, [designers] can alter the frame of reference in which we see the human form, and in so doing, [they] can create illusions or effects that would not be possible in any other way." 36 In this sense, they are the same as camouflage or high-visibility patterns that serve a particular function. Unlike a painting or a drawing of a cartoon character, they do not exist merely to portray their own appearance or convey information.

As we argue in the following Part, the Copyright Act treats as functional aspects of visual design that influence the perception of another object, including the human body. Accordingly, as a matter of copyright statute and policy, the incorporation of design techniques that produce dependent value are unprotectable. Similarly, trademark and design patent laws must grapple with the issue whether such functional aspects of fashion designs are unprotectable. We now address these laws in turn, beginning with copyright law.

\section{Fashion's Function in Copyright Law}

Congress and the courts have long expressed concern about the misuse of copyright law to protect functional objects from market competition. ${ }^{37}$

32 See id. at 244.

33 See id. at 124 (illustrating this effect with the use of Korean traditional dress).

34 According to Marian Davis:

A garment may have a purpose, or reason for being, in any or all three design aspects. Its functional, physical purpose may be to allow the wearer to ski comfortably and safely, to sit comfortably, or to move and survive in space. Its structural purpose is to allow it to fit and to perform. Decorative, visual purposes might be to increase night visibility, or the attractiveness of the wearer, or to provide visual identification of a nurse or policeman, qualities that can only be seen.

DAvis, supra note 12 , at 15 .

35 Justin Hughes discusses how trademarks take advantage of features of the human cognitive apparatus. See Justin Hughes, Cognitive and Aesthetic Functionality in Trademark Law, 36 Cardozo L. Rev. 1227 (2015).

36 Horn \& Gurel, supra note 12 , at 314.

37 See Mazer v. Stein, 347 U.S. 201, 217-18 (1954); Baker v. Selden, 101 U.S. 99, 101-06 (1879); H.R. ReP. No. 94-1476, at 54-55 (1976), reprinted in 1976 U.S.C.C.A.N. 5659, 5667-68; J.H. Reichman, Design Protection in Domestic and Foreign Copyright Law: From the Berne Revision of 1948 to the Copyright Act of 1976, 1983 Duke L.J. 1143 (discussing history of American legal protection of design); $c f$. TrafFix Devices, Inc. v. Mktg. Displays, Inc., 532 U.S. 23, 28-35 (2001) (elaborating on trademark law's statutory prohibition on protecting functional matter, and the existence of a utility patent on that matter being strong evi- 
The fashion industry, in particular, has proven a consistent source of consternation in this regard. ${ }^{38}$ Over a century ago, one court explained that "a manufacturer of unpatented articles cannot practically monopolize their sale by copyrighting a catalogue containing illustrations of them." ${ }^{9}$ As the Star Athletica case recently decided by the U.S. Supreme Court ${ }^{40}$ indicates, many in the fashion industry are still seeking haven for their designs within copyright law. In this Part, we review the general structure of the copyright-patent divide in intellectual property law and the doctrinal techniques that copyright law has historically used to screen out functional content. We then set out how copyright law and policy lead to the conclusion that fashion design features that affect the perception of the wearer are not protectable.

\section{A. The Separate Spheres of Copyright and Patent Laws}

In the United States, copyright and patent laws share the same constitutional grounding. The U.S. Constitution grants Congress power " $[\mathrm{t}] \mathrm{o}$ promote the Progress of Science and useful Arts, by securing for limited Times to Authors and Inventors the exclusive Right to their respective Writings and Discoveries." ${ }^{11}$ Typically, this language is read to establish separate domains

dence of such functionality); Fashion Originators' Guild of Am., Inc. v. FTC, 312 U.S. 457 (1941) (deeming a fashion industry organization's attempts to stop garment design piracy to be anticompetitive in contravention of the Sherman Act, and emphasizing that copyright law, as it existed at the time, did not allow the prevention of such privacy); Nat'l Cloak \& Suit Co. v. Standard Mail Order Co., 191 F. 528, 528 (S.D.N.Y. 1911) ("[A] manufacturer of unpatented articles cannot practically monopolize their sale by copyrighting a catalogue containing illustrations of them. From a comparison of the illustrations upon which complainant relies, the fair inference would seem to be that defendant makes some garments which are identical with complainant's and offers them for sale.”).

38 See, e.g., Fashion Originators' Guild, 312 U.S. 457 (deeming efforts to stop garment design piracy a violation of the Sherman Act, and emphasizing that copyright law, as it then existed, did not provide a basis for preventing such piracy). The relationship between intellectual property law and the fashion industry has garnered substantial scholarly attention. See Jonathan M. Barnett, Shopping for Gucci on Canal Street: Reflections on Status Consumption, Intellectual Property, and the Incentive Thesis, 91 VA. L. REv. 1381 (2005) (suggesting when producers will tolerate counterfeiting); Barton Beebe, Intellectual Property Law and the Sumptuary Code, 123 HARv. L. REv. 809, 810 (2010) (evaluating "intellectual property law's emerging role as a modern form of sumptuary law"); C. Scott Hemphill \& Jeannie Suk, The Law, Culture, and Economics of Fashion, 61 Stan. L. Rev. 1147 (2009) (arguing for a limited right against copying); Kal Raustiala \& Christopher Sprigman, The Piracy Paradox: Innovation and Intellectual Property in Fashion Design, 92 VA. L. Rev. 1687 (2006) (arguing that the lack of IP protection for fashion tends to both enable trends and speed up their obsolescence).

39 Nat'l Cloak E Suit Co., 191 F. at 528.

40 Star Athletica, L.L.C. v. Varsity Brands, Inc., 137 S. Ct. 1002 (2017).

41 U.S. Const. art. I, $\$ 8$, cl. 8. For more on the history of this provision, see Jeanne C. Fromer, The Intellectual Property Clause's External Limitations, 61 Duke L.J. 1329 (2012); Dotan Oliar, Making Sense of the Intellectual Property Clause: Promotion of Progress as a Limitation on Congress's Intellectual Property Power, 94 GEo. L.J. 1771 (2006). 
for copyright law and patent law. ${ }^{42}$ Congress's implementations of copyright and patent laws follows this conventional divide: Copyright law protects authors' writings, while patent law protects inventors' discoveries. ${ }^{43}$ Put another way, copyright law is the province of expression and aesthetics, while patent law is the province of utility and functionality. ${ }^{44}$ Both fields seek to optimize creative production within their spheres, but they both adopt very different legal mechanisms to do so.

Patents can confer substantial market power on their owners, enabling them to charge higher prices for access to the protected technology than they otherwise would. ${ }^{45}$ These higher prices and diminished market competition are deemed worthwhile, however, because they provide valuable incentives to invest in creating and disseminating new and useful technologies. ${ }^{46}$ The world is a better place, so the story goes, when inventors are given incentives to develop and disclose their inventions, even if this comes at the cost of higher prices. ${ }^{47}$ But not all "inventions" are worth this tradeoff. Patent law establishes relatively high standards for obtaining its protection. Inventors who desire patent rights must submit to an expensive patent examination by the Patent and Trademark Office of their inventions' utility, novelty, and nonobviousness. ${ }^{48}$ This means that the inventions had never existed before and that other people in the relevant field would not easily have thought of them if they had tried. Only $75 \%$ of utility patents get granted, and the pro-

42 See Dotan Oliar, The (Constitutional) Convention on IP: A New Reading, 57 UCLA L. REv. 421 (2009) (indicating that this is the conventional reading, but proposing that it is wrong); Lawrence B. Solum, Congress's Power To Promote the Progress of Science: Eldred v. Ashcroft, 36 Loy. L.A. L. REv. 1 (2002) (discussing issues of constitutional interpretation of the Copyright Clause before the Supreme Court in Eldred v. Ashcroft, 537 U.S. 186 (2003)). On the constitutional foundations of design patents, see Ralph D. Clifford \& Richard J. PeltzSteele, The Constitutionality of Design Patents, 14 Chi.-Kent J. Intell. Prop. 553 (2015).

43 Compare 17 U.S.C. $\$ 102$ (2012) (stating that "[c]opyright protection subsists . . . in original works of authorship fixed in any tangible medium of expression," and listing as "[w] orks of authorship," among other things, "literary works" and "pictorial, graphic, and sculptural works"), with 35 U.S.C. \$ 101 (2012) ("Whoever invents or discovers any new and useful process, machine, manufacture, or composition of matter, or any new and useful improvement thereof, may obtain a patent therefor . . ..").

44 See Christopher Buccafusco, A Theory of Copyright Authorship, 102 VA. L. REv. 1229 (2016); Jeanne C. Fromer, A Psychology of Intellectual Property, 104 Nw. U. L. REv. 1441 (2010).

45 Mark A. Lemley, The Economics of Improvement in Intellectual Property Law, 75 TEx. L. REv. 989, 996-97 (1997).

46 Id. at $993-96$.

47 Id.

48 See 35 U.S.C. $\$ \S 101-103$, 131. See generally Christopher Buccafusco, Zachary C. Burns, Jeanne C. Fromer \& Christopher Jon Sprigman, Experimental Tests of Intellectual Property Laws' Creativity Thresholds, 92 TEx. L. REv. 1921 (2014) (exploring, via experimentation, how varying creativity thresholds affects creativity in different artistic and scientific domains); David Fagundes \& Jonathan S. Masur, Costly Intellectual Property, 65 VAND. L. REv. 677 (2012) (analyzing the differential screening for protectability in patent and copyright laws); Fromer, supra note 44, at 1483-1508 (probing the differences in patent and copyright laws' protectability thresholds). 
cedure typically costs $\$ 22,000 .^{49}$ Moreover, once granted, patent protection lasts only for twenty years from the application date. ${ }^{50}$

Contrast this situation with copyright law. Although the term of protection was a fairly short maximum of twenty-eight years under the first copyright statute, ${ }^{51}$ copyright protection now lasts for much longer than does patent protection. Authors typically receive copyright protection in their works for their entire lives plus an additional 70 years post-mortem. ${ }^{52}$ In addition, copyrights are extraordinarily easy to obtain. Under the 1976 Act, copyright vests without need for further action at the moment that a work is fixed in a tangible medium of expression-as soon as it is filmed, drawn, or written down. ${ }^{53}$ In contrast to the Patent and Trademark Office, the Copyright Office plays little to no role in screening out inappropriate claims to protection. ${ }^{54}$ Moreover, to be protectable works do not need to be novel and nonobvious, but rather only "original," that is, independently created and that they exhibit a very modest creative spark. ${ }^{55}$ This threshold is much lower than the one imposed by patent law. ${ }^{56}$

In light of the differences between obtaining patents and copyrights, there is a sizeable risk that creators will attempt to use copyright law to obtain "backdoor patents." 57 Patent law allows inventors to protect functional creations and to obtain competitive advantages, but only upon showing that they have made a meaningful contribution to scientific or technological progress. Accordingly, to ensure that creators do not take advantage of its lower protection thresholds and longer duration, copyright law imposes screening mecha-

49 Jonathan S. Masur, Costly Screens and Patent Examination, 2 J. Legal Analysis 687, 695, $700(2010)$.

5035 U.S.C. $\$ 154$ (a) (2).

51 Copyright Act of 1790, ch. 15, § 1, 1 Stat. 124, 124 (repealed 1802).

5217 U.S.C. \$ 302(a) (2012).

53 See id. \$102(a).

54 One can-and has incentive to-register copyrights with the Copyright Office. Id. $\S \S$ 409-412; Dotan Oliar, Nathaniel Pattison \& K. Ross Powell, Copyright Registrations: Who, What, When, Where, and Why, 92 Tex. L. Rev. 2211, 2215-19 (2014). The Copyright Office can refuse registration, but that is no bar to statutory protection when courts understand copyright law contrary to the Copyright Office. See, e.g., Atari Games Corp. v. Oman, 979 F.2d 242 (D.C. Cir. 1992) (granting copyright protection to video game after Copyright Office had refused registration).

5517 U.S.C. $\$ 102(a)$; Feist Publ'ns, Inc. v. Rural Tel. Serv. Co., 499 U.S. 340, 345-47 (1991).

56 See Buccafusco, Burns, Fromer \& Sprigman, supra note 48, at 1926-31.

57 See Baker v. Selden, 101 U.S. 99, 102 (1879) ("The novelty of the art or thing described or explained has nothing to do with the validity of the copyright. To give to the author of the book an exclusive property in the art described therein, when no examination of its novelty has ever been officially made, would be a surprise and a fraud upon the public. That is the province of letters-patent, not of copyright. The claim to an invention or discovery of an art or manufacture must be subjected to the examination of the Patent Office before an exclusive right therein can be obtained; and it can only be secured by a patent from the government.”); Viva R. Moffat, Mutant Copyrights and Backdoor Patents: The Problem of Overlapping Intellectual Property Protection, 19 Berkeley Tech. L.J. 1473 (2004). 
nisms that exclude functional works and features from protection. The Supreme Court's foundational copyright decision in Baker v. Selden ${ }^{58}$ refuses to allow authors to use copyright law to obtain backdoor patent protection for the useful objects or methods described in their expressive works, such as manuals or scientific articles. ${ }^{59}$ The copyright statute codifies this holding: "In no case does copyright protection for an original work of authorship extend to any idea, procedure, process, system, method of operation, concept, principle, or discovery, regardless of the form in which it is described, explained, illustrated, or embodied in such work." 60

Courts have applied this exclusionary rule in many contexts, including importantly to exclude from copyright protection crucial aspects of computer software that are dictated by efficiency, hardware specifications, and, more broadly, anything that extends beyond the expressive aspects of the code to its functional aspects. ${ }^{61}$ Pertinently, because copyright law refuses to allow backdoor patents, courts apply the merger doctrine to find expression uncopyrightable when there is only one or a very limited number of ways to express a function. ${ }^{62}$ In these cases, protecting the expression would essentially provide copyright coverage to the function, so the merger doctrine treats the function and expression as merged, rendering the expression just as uncopyrightable as the function. ${ }^{63}$ On the same basis, courts also find such functionally constrained expression to be one of the few categories of expression that fail to meet copyright's low threshold of originality. ${ }^{64}$

Although virtually all areas of copyright are at risk of improperly protecting functional content, these concerns are heightened for certain two- and three-dimensional works. Copyright law has taken a targeted approach to excluding functional aspects of these "pictorial, graphic, and sculptural works," 65 which we discuss and for which we offer an analytical framework in the next Section.

58101 U.S. 99 (1879).

59 Id. at 102-04.

6017 U.S.C. $\$ 102$ (b) (2012).

61 See Comput. Assocs. Int'l, Inc. v. Altai, Inc., 982 F.2d 693, 707-10 (2d. Cir. 1992); see also Buccafusco \& Lemley, supra note 6.

62 See, e.g., Lexmark Int'l, Inc. v. Static Control Components, Inc., 387 F.3d 522, 535-38 (6th Cir. 2004).

63 See, e.g., id. See generally Jeanne C. Fromer, An Information Theory of Copyright Law, 64 EMORY L.J. 71 (2014) (explaining the merger doctrine as part of an information theory of copyright law); Pamela Samuelson, Reconceptualizing Copyright's Merger Doctrine, 63 J. CopYRIGHT SOC'y U.S.A. 417 (2016) (reviewing 150 judicial opinions discussing or applying the merger doctrine in copyright law). For the same reason, courts find no infringement when the defendant's work copies unprotected functional matter. See, e.g., Comput. Assocs. Int'l, 982 F.2d at 707-10.

64 Lexmark Int'l, 387 F.3d at 537-41.

6517 U.S.C. $\$ 102(a)(5)$. 


\section{B. Screening Functionality in Pictorial, Graphic, and Sculptural Works}

The design of an automobile will often be aesthetically pleasing. ${ }^{66}$ Yet the design will also affect the car's aerodynamics and fuel efficiency. ${ }^{67}$ To the extent that copyright law protects the aesthetic features of the design, it risks also protecting utilitarian function, the province of patent law. Consistent with this concern, Congress established a general rule against copyright protection for so-called "useful article[s]," subject to a narrow exception for expressive features of a useful article that are separable from its functional aspects. ${ }^{68}$

Specifically, the Copyright Act provides that "[p]ictorial, graphic, and sculptural works" include "works of artistic craftsmanship insofar as their form but not their mechanical or utilitarian aspects are concerned." 69 Further, the design of a work that constitutes a "useful article" is protectable "only if, and only to the extent that, such design incorporates pictorial, graphic, or sculptural features that can be identified separately from, and are capable of existing independently of, the utilitarian aspects of the article." 70 In short, to be protectable a product design must exhibit expressive "pictorial, graphic, or sculptural features" (we refer to these as "expressive" features throughout) that are separable from its "utilitarian aspects."71 If a useful article has no expressive features or if the expressive features are inseparable from its utilitarian aspects, it should not receive copyright protection.

Congress was aware that this rule meant many useful works that are visually appealing would be unprotected by copyright, but it considered this appropriate in light of the risks to competition posed by more expansive copyright protection and the availability of design patents for industrial designs. ${ }^{72}$ Congress concluded that leaving some works with expressive features unprotected by copyright was preferable to allowing functional objects to gain lengthy legal protection while avoiding the high inventive threshold and careful examination of the patent system. ${ }^{73}$

Before discussing copyright law's treatment of garment designs, it is essential to understand how copyright law has handled the challenge of sepa-

66 See, e.g., H.R. REP. No. 94-1476, at 55 (1976), reprinted in 1976 U.S.C.C.A.N. 5659, 5668; Sarah Schleuning \& Ken Gross, Dream Cars: Innovative Design, Visionary Ideas (2014).

67 See, e.g., Thomas Schuetz, Aerodynamics of Road Vehicles (5th ed. 2015).

68 See 17 U.S.C. $\$ 101$.

$69 I d$. (emphasis added) (internal quotation marks omitted).

$70 \quad I d$.

71 Id

72 H.R. Rep. No. 94-1476, at 49-50, 54-55 (1976), reprinted in 1976 U.S.C.C.A.N. 5659, 5662-63, 5667-68; see Star Athletica, L.L.C. v. Varsity Brands, Inc., 137 S. C.. 1002, 1007 (2017) ("Congress has provided copyright protection for original works of art, but not for industrial designs.”); supra Section II.A.

73 H.R. ReP. No. 94-1476, at 49-50, 54-55; see supra Section II.A; cf. Baker v. Selden, 101 U.S. 99, 102 (1879) ("The claim to an invention or discovery of an art or manufacture must be subjected to the examination of the Patent Office before an exclusive right therein can be obtained ...."). 
rating form and function more generally. When dealing with pictorial, graphic, or sculptural works, copyright law distinguishes between those works that constitute "useful articles" and those that do not. According to the Act, a useful article is "an article having an intrinsic utilitarian function that is not merely to portray the appearance of the article or to convey information."74

This definition is vitally important to understanding copyright law's treatment of functionality, and it has two essential purposes. First, the definition explains that only those works that have an intrinsic utilitarian function should be treated as useful articles. "Intrinsic" in this sense means inherent or essential. ${ }^{75}$ The Act differentiates between works that essentially have at least one function and those that do not essentially have any function-that is, those that are essentially expressive.

Second, the definition clarifies how to determine whether some characteristic of a work should be treated as functional or expressive. Aspects of a work that "merely . . . portray the appearance of the article or . . . convey information" are not functional aspects of the work. ${ }^{76}$ They are, instead, expressive features. This distinction is necessary to effectuate the statutory requirement that

the design of a useful article, as defined in this section, shall be considered a pictorial, graphic, or sculptural work only if, and only to the extent that, such design incorporates pictorial, graphic, or sculptural features that can be identified separately from, and are capable of existing independently of, the utilitarian aspects of the article. ${ }^{77}$

Consider a copyright claim in an original painting. A painting is clearly a "pictorial, graphic, or sculptural work," so we must then decide whether the painting is a "useful article." The answer, in virtually all cases, is that it is not a useful article. Most paintings do not have an intrinsic utilitarian function. Instead, they exist to portray their own appearance. When we think about why most paintings are painted and why they are valued by consumers, we focus on their representational characteristics. ${ }^{78}$ Indeed, virtually all of the decisions that an artist makes about the content of a painting are concerned with representational or depictive ends. This is not to say that a painting can have no function. It may successfully cover a hole in the wall, in much the same way that a book can serve as a doorstop. Yet this sort of utilitarian

$74 \quad 17$ U.S.C. $\$ 101$.

75 See, e.g., Intrinsic, Black's Law Dictionary (9th ed. 2009) (defining "intrinsic" as "[b] elonging to a thing by its very nature; not dependent on external circumstances; inherent; essential").

$76 \quad 17$ U.S.C. $§ 101$.

77 Id.

78 See Varsity Brands, Inc. v. Star Athletica, LLC, 799 F.3d 468, 490 (6th Cir. 2015); cf. Bleistein v. Donaldson Lithographing Co., 188 U.S. 239, 249 (1903) (“[P]ainting and engraving unless for a mechanical end are not among the useful arts, the progress of which Congress is empowered by the Constitution to promote."). Below we discuss the relationship between creators and consumers in the determination of a work's functional features. See infra subsection II.C.2. 
function is one that is shared by all physical objects and is thus not intrinsic, or essential, to a painting or a book in any meaningful way. This sort of nonintrinsic functionality does not magically make paintings or other pictorial, graphic, or sculptural works intrinsically utilitarian. Most paintings, then, are by application of the copyright statute, not useful articles.

Now consider the design of a stylish bicycle rack. ${ }^{79}$ Although the design may have significant aesthetic features and although it may have won awards for the quality of its design, the bicycle rack has an intrinsic utilitarian function: to hold bicycles securely. The rack was made to hold bicycles, and it is purchased by consumers who want to use it for that purpose. This use is obviously different from typical copyrightable expression, which merely portrays the appearance of an article or conveys information. Similarly, the designs of "pictorial, graphic, or sculptural" objects like mannequins, floor tiles, and, of course, garments, are useful articles. They each have an intrinsic function beyond "portray[ing] the appearance of the article or . . . convey[ing] information." 80 They are, as "useful articles," then subject to a rigorous separability analysis to determine whether they can support a valid copyright.

The copyright statute sets out that

the design of a useful article ... shall be considered a pictorial, graphic, or sculptural work only if, and only to the extent that, such design incorporates pictorial, graphic, or sculptural features that can be identified separately from, and are capable of existing independently of, the utilitarian aspects of the article. ${ }^{81}$

This language indicates that Congress intended to extend copyright protection only to some components of a limited class of useful articles-their separable "pictorial, graphic, or sculptural" (expressive) features. The first step in a separability analysis, then, must involve determining which components of a work are its expressive features and which are its utilitarian aspects. A court cannot determine whether the former are separable from the latter until it has determined which are which. ${ }^{82}$

This inquiry has been the key component to successful application of the useful articles doctrine in fashion design and elsewhere. In effect, a court is asked to parse the various features of a design and to characterize each of those features. The Copyright Act specifically contemplates that a

79 See, for example, the bicycle rack denied copyrightability in Brandir International, Inc. v. Cascade Pacific Lumber Co., 834 F.2d 1142 (2d Cir. 1987).

8017 U.S.C. $§ 101$.

$81 I d$.

82 See, e.g., Star Athletica, 799 F.3d at 490-91; Pivot Point Int'l, Inc. v. Charlene Prods., Inc., 372 F.3d 913, 932 (7th Cir. 2004) (Kanne, J., dissenting) ("[T] he statute requires, on its face, that sculptural features must be separately identified from the utilitarian aspects of the article."). In fact, as we discuss below, we think the Supreme Court erred in its Star Athletica decision by failing to categorize the design's features, which led in turn to a flawed outcome in the case. See infra Part III. 
particular design component can fall into one of the three categories like we described in Part I:

(1) only pictorial, graphic, or sculptural (or "expressive");

(2) only utilitarian (or functional); or

(3) both expressive and utilitarian.

The first two categories are straightforward. They encompass design features that are either purely expressive or purely utilitarian, respectively. A cartoon character screen-printed on the front of a t-shirt is likely to be purely expressive, for example, while the shape of an internal part of an automotive engine is purely functional.

The existence and content of the third category may seem less clear, but the statute undoubtedly recognizes the existence of dual-nature components, and it explains how they should be treated. On its face, the Copyright Act recognizes the existence of what we call dual-nature components by acknowledging that there are "pictorial, graphic, or sculptural features" that cannot "be identified separately from" the "utilitarian aspects of the article." 83 This language indicates that a component of a design, such as the leg of a chair, may be simultaneously expressive and functional. The back of an Eames chair is both a brilliant work of visual design and a terrific example of functional ergonomic engineering. ${ }^{84}$

Indeed, the fundamental justification for the useful articles doctrine has been to exclude from copyright protection aspects of works that exhibit both expression and function. ${ }^{85}$ There would be little need for separability analysis if all components of a design could be designated as either expressive or functional, because copyright law could simply indicate that only the expressive features are protectable. Separability analysis exists precisely because design aspects that are expressive can-and, as discussed in the previous Part, in the case of clothing often will-serve utilitarian purposes.

Until the Supreme Court recently ruled on separability in Star Athletica, Congress and lower courts recognized two forms of separability-physical and conceptual-that could form the basis of valid copyrights. ${ }^{86}$ Physical separability existed, straightforwardly, when an expressive pictorial, graphic, or sculptural feature could be physically removed from an otherwise useful

8317 U.S.C. $\$ 101$.

84 See John R. Berry, Herman Miller: The Purpose of Design 85 (2004).

85 Copyright law cannot both protect the expressive features of the uniforms and preserve their functional aspects from protection when they are the same. Cf. Morrissey v. Procter \& Gamble Co., 379 F.2d 675, 678-79 (1st Cir. 1967) (holding that copyright does not protect expression whose associated idea can be expressed in very few ways, so that the idea effectively merges with the expression, for the reason that in such cases copyright would then unreasonably protect ideas); Samuelson, supra note 63, at 417.

86 H.R. REP. No. 94-1476, at 55 (1976), reprinted in 1976 U.S.C.C.A.N. 5659, 5668 ("Unless the shape of an automobile, airplane, ladies' dress, food processor, television set, or any other industrial product contains some element that, physically or conceptually, can be identified as separable from the utilitarian aspects of that article, the design would not be copyrighted ...."). 
article without affecting the article's utility. ${ }^{87}$ For example, an expressive hood ornament is typically physically separable from the utilitarian automobile to which it is attached. ${ }^{88}$ Conceptual separability had been less clear-cut, leading courts and scholars to have articulated varying tests to ascertain it. ${ }^{89}$ Typically, these cases had involved situations in which the expressive and functional aspects of the design are more intimately related. Even though the expressive features could not be simply ripped off of the useful article, they may have nonetheless been protectable in certain circumstances. Under what circumstances, then, could the pictorial, graphic, and sculptural features of a design be conceived separately from and exist independently of the design's functional aspects? In the past, for example, courts held to be conceptually separable-and therefore copyrightable - the ornamental features of belt buckles ${ }^{90}$ and a mannequin face. ${ }^{91}$ By contrast, courts held not to be separable plastic torsos used to display clothing, ${ }^{92}$ a bicycle rack, ${ }^{93}$ and casino uniform designs. ${ }^{94}$

In sum, it is essential to the policies underlying both copyright and patent laws that copyright law distinguish expression from function in determining protectability. Congress sought to do that with the useful articles doctrine by analyzing whether a useful article's expressive features are separable from its functional aspects. We now turn to how to think about fashion designs within this context.

\section{The Functionality of Garment Design Features}

Copyright law's useful articles doctrine is intended to handle cases involving works that incorporate both expression and function. Applying this doctrine to fashion designs has proved especially challenging to courts, as they try to sort and separate the aspects of garments that are expressive from those that are functional. In this Part, we offer a robust approach to understanding the nature of fashion's functionality. Our approach is grounded in the current copyright statute and responds to the Supreme

87 Star Athletica, 799 F.3d at 481-82 (quoting U.S. Copyright OfFice, Compendium of Copyright Office Practices $§ 924.2($ A) (3d ed. 2014)).

$88 I d$.

89 See id. at 484-85 (listing nine different tests and describing a circuit split with regard to them).

90 Kieselstein-Cord v. Accessories by Pearl, Inc., 632 F.2d 989, 993 (2d Cir. 1980) (holding that the ornamental features of the belt buckles were conceptually separable "sculptural elements" because these features are "primary" to the buckle's "subsidiary utilitarian function”).

91 Pivot Point Int'l, Inc. v. Charlene Prods., Inc., 372 F.3d 913, 931 (7th Cir. 2004).

92 Carol Barnhart Inc. v. Econ. Cover Corp., 773 F.2d 411, 418-19 (2d Cir. 1985) (explaining that the expressive features were not conceptually separable because they were objectively necessary to the performance of the torsos' utilitarian function of displaying actual clothing on a human-like torso).

93 Brandir Int'l, Inc. v. Cascade Pac. Lumber Co., 834 F.2d 1142, 1146-47 (2d Cir. 1987).

94 Galiano v. Harrah’s Operating Co., 416 F.3d 411, 419-22 (5th Cir. 2005). 
Court's recent Star Athletica decision. Correctly applied, it appropriately limits the scope of copyright protection for garment design to only those features that are purely expressive. According to our approach, components of a garment design should be treated as functional not only if they are mechanically or technologically functional, but also if they are valued for their ability to influence the way that the wearer is perceived. These components are prevalent in fashion design, and even if they are also expressive, must be screened out of any copyright protection granted to an author. We explain the analysis below.

To analyze the copyrightability of fashion designs, or for that matter any ostensibly useful article, one must ask and answer a series of questions. The first step of the relevant inquiry is whether the works at issue are pictorial, graphic, or sculptural works. Fashion designs are "pictorial, graphic, or sculptural works."95 They qualify as such when they are design drawings as "two-dimensional . . . works of . . . graphic . . . art," and any resulting garments made from those designs ought to be characterized as "sculptural works," or "three-dimensional works of . . . art."96

Given that garment designs are properly characterized as pictorial, graphic, or sculptural works, the second relevant question is whether the designs are for "useful articles." According to the copyright statute, separability analysis is required to assess copyrightability only for pictorial, graphic, and sculptural works that qualify as useful articles. ${ }^{97}$ Garments and their designs fall squarely within the statutory definition of a "useful article": "an article having an intrinsic utilitarian function that is not merely to portray the appearance of the article or to convey information." ${ }^{98}$ As discussed in Part I, garments are meant to be worn and when worn are meant to provide warmth, modesty, and performance for a range of purposes. ${ }^{99}$

Note that even though a drawing of a dress is not necessarily itself a useful article, the copyright in the drawing does not extend protection to the

95 See, e.g., Varsity Brands, Inc. v. Star Athletica, LLC, 799 F.3d 468, 489 (6th Cir. 2015) (quoting 17 U.S.C. $\$ 101$ (2012)) (internal quotation marks omitted).

96 See 17 U.S.C. $\$ 101$ (defining "pictorial, graphic, and sculptural works").

97 Id:; see also Am. Dental Ass'n v. Delta Dental Plans Ass'n, 126 F.3d 977, 980 (7th Cir. 1997) (emphasizing that the separability test for useful articles that are sculptural works has no application for literary works).

9817 U.S.C. $\$ 101$.

99 See also Jovani Fashion, Ltd. v. Cinderella Divine, Inc., 808 F. Supp. 2d 542, 550-51 (S.D.N.Y. 2011) (holding that the function of a prom dress, for example, is to cover the body in an attractive way for a special occasion); DAVIs, supra note 12, at 17, 19 (indicating, for example, that "clothing can protect against extreme temperatures, wind, moisture, radiation, insects and other creatures, thorns, fungi and bacteria, plant secretions, chemicals, excessive friction, and the like," and that "[c]lothing for active sports must provide protection, comfort, absorbency, and freedom of movement, as well as visual identification”); 2 PATRY, supra note $14, \S 3: 151$ (discussing how features of a garment like the shapes of the neckline, sleeves, skirt shape, trouser cut, or pockets are design elements inextricably connected with the utilitarian aspects of clothing: pockets store pencils or pens; pants and skirts cover the legs; shirts cover the torso modestly or less modestly depending on the neckline). 
creation of a three-dimensional dress that would be a useful article. ${ }^{100}$ Section 113(b) of the Copyright Act explains that "the owner of copyright in a work that portrays a useful article" does not obtain "any greater or lesser rights . . . to the making, distribution, or display of the useful article so portrayed than those afforded to such works under the law."101 So, for example, an artist who draws a picture of a car may obtain a copyright in her drawing and prevent others from copying the drawing in their own drawings, but her copyright does not give her the exclusive right to produce actual functional cars based on her drawing. ${ }^{102}$ Similarly, the creator of the "The Man with

100 See 17 U.S.C. \$ 113(b); see also Star Athletica, L.L.C. v. Varsity Brands, Inc., 137 S. Ct. 1002, 1013 n.2 (2017) ("A drawing of a shovel could, of course, be copyrighted. And, if the shovel included any artistic features that could be perceived as art apart from the shovel, and which would qualify as protectable pictorial, graphic, or sculptural works on their own or in another medium, they too could be copyrighted. But a shovel as a shovel cannot."); $i d$. at 1033 (Breyer, J., dissenting) ("The law has long recognized that drawings or photographs of real world objects are copyrightable as drawings or photographs, but the copyright does not give protection against others making the underlying useful objects. That is why a copyright on Van Gogh's painting would prevent others from reproducing that painting, but it would not prevent others from reproducing and selling the comfortable old shoes that the painting depicts." (citation omitted)); cf. Baker v. Selden, 101 U.S. 99, 103 (1879) ("The copyright of a book on perspective, no matter how many drawings and illustrations it may contain, gives no exclusive right to the modes of drawing described, though they may never have been known or used before. By publishing the book, without getting a patent for the art, the latter is given to the public. The fact that the art described in the book by illustrations of lines and figures which are reproduced in practice in the application of the art, makes no difference. Those illustrations are the mere language employed by the author to convey his ideas more clearly. Had he used words of description instead of diagrams (which merely stand in the place of words), there could not be the slightest doubt that others, applying the art to practical use, might lawfully draw the lines and diagrams which were in the author's mind, and which he thus described by words in his book.").

10117 U.S.C. $\$ 113(\mathrm{~b})$.

102 Star Athletica, 137 S. Ct. at 1010 ("Nor could someone claim a copyright in a useful article merely by creating a replica of that article in some other medium-for example, a cardboard model of a car. Although the replica could itself be copyrightable, it would not give rise to any rights in the useful article that inspired it.”). In DC Comics v. Towle, 802 F.3d 1012 (9th Cir. 2015), the U.S. Court of Appeals for the Ninth Circuit ruled in favor of a lawsuit brought by copyright owners of the Batmobile as it was visually depicted in Batman comic books, television programs, and movies against a manufacturer of replica kits that attach to actual automobiles to make them look like the Batmobile. See id. at 1027. The court, wrongly in our view, failed to consider whether the copyright in the depiction of a useful article like an automobile could extend protection to the production of actual car parts. See generally $i d$. The district court had addressed this question and found that because many of the Batmobile's functional elements were not functional in the real world, they were not useful. DC Comics v. Towle, 989 F. Supp. 2d 948, 969-70 (C.D. Cal. 2013). It had also found that the design of the bat logos, hubcaps, and the car's frame were separable "artistic feature[s]" of the design. Id. at 970. Although the Batmobile may have had separable features that entitled it to copyright protection under the useful articles doctrine, the Ninth Circuit did not discuss separability. See generally DC Comics, 802 F.3d 1012. 
the Yellow Hat" character in Curious George receives copyright protection for the drawing of the character. ${ }^{103}$ This copyright would give the author the exclusive right to depict the character in other two-dimensional media, including cartoons and movies, and even to create three-dimensional sculptures or toys based on the character. ${ }^{104}$ That copyright, however, would not extend to the production of actual yellow hats, because hats are useful articles without separable copyrightable features. Clearly, allowing artists to secure intellectual property protection for functional objects simply because they draw them would subvert the whole purpose of patent law's stringent novelty, nonobviousness, and examination requirements. ${ }^{105}$

Because garment designs are useful articles, they are subjected to the separability analysis discussed above. ${ }^{106}$ As noted above, the most important step in this analysis involves the identification and categorization of the components of a claimed design. A court must determine which components of the design are purely expressive, which are purely functional, and which are dual-nature-that is, that they simultaneously affect the aesthetics and the utility of the garment.

We think that the Copyright Act treats aspects of garment design that influence the perception of the wearer's body as "utilitarian features" of a useful article, although they may also be expressive "pictorial, graphic, or sculptural" aspects of the article. The reason is that the copyright statute defines a useful article as one having "an intrinsic utilitarian function that is

103 See H.A. Rey \& Margret Rey, Curious George (1941).

104 Toys are not necessarily considered "useful articles" under the Copyright Act. See, e.g., Gay Toys, Inc. v. Buddy L Corp., 703 F.2d 970, 973 (6th Cir. 1983) (“[A] toy airplane is merely a model which portrays a real airplane. To be sure, a toy airplane is to be played with and enjoyed, but a painting of an airplane, which is copyrightable, is to be looked at and enjoyed. Other than the portrayal of a real airplane, a toy airplane, like a painting, has no intrinsic utilitarian function.").

105 See supra Section II.A. This understanding of $\S 113$ (b) is not contrary to $\S 113$ (a), which provides that "[s]ubject to the provisions of subsection[ ] (b) ... of this section, the exclusive right to reproduce a copyrighted pictorial, graphic, or sculptural work in copies ... includes the right to reproduce the work in or on any kind of article, whether useful or otherwise." 17 U.S.C. $§ 113(a)$. The reason that $\$ 113$ (a) does not permit owners of a copyright in a drawing of a dress to make that dress if it is a useful article lacking in separability is that $\S 113(\mathrm{a})$ is subject to $\S 113(\mathrm{~b})$, which forbids such an extension of copyright law to cover useful articles. The Supreme Court's opinion in Star Athletica, which purports to be an exercise in statutory interpretation, focuses on $\S 113$ (a) to the exclusion of $\S 113$ (b), despite Congress's explicit limitation of $\S 113(\mathrm{a})$ by $\S 113(\mathrm{~b})$. The majority opinion does not even mention $\S 113(\mathrm{~b})$, despite otherwise quoting from $\S 113(\mathrm{a})$. See generally Star Athletica, 137 S. Ct. 1002. That leads the Supreme Court to interpret $§ 113$ (a) erroneously to mean that

[t] he ultimate separability question, then, is whether the feature for which copyright protection is claimed would have been eligible for copyright protection as a pictorial, graphic, or sculptural work had it originally been fixed in some tangible medium other than a useful article before being applied to a useful article.

$I d$. at 1011 (referring to $\S 113(\mathrm{a})$ as a basis for this interpretation).

106 See supra Section II.B. 
not merely to portray the appearance of the article or to convey information." 107 As discussed in the previous section, the Act distinguishes between useful article features that "merely portray the appearance of the article or . . . convey information" and useful article features that have additional utility. By this distinction, an aspect of a useful article that "merely ... portray[s] [its] appearance ... or . . convey[s] information" is not considered a utilitarian feature. It is purely an expression of authorship. ${ }^{108}$ By contrast, an aspect of a useful article that does not merely portray its appearance or convey information is a utilitarian feature of that article.

The statute itself thereby defines when an article or an article's design feature has a utilitarian function. It should be apparent that this statutory specification defines expressive-or pictorial, graphic, or sculptural-features restrictively. By the statute's terms, an expressive feature cannot have a purpose other than-or additional to-portraying its own appearance or conveying information. Otherwise, it is utilitarian. For this reason, as we discuss in greater detail in Section II.D, dual-nature features as discussed in the previous section are statutorily utilitarian, not expressive.

In the context of the useful articles doctrine, the Copyright Act establishes a distinction between aspects of designs that are valued inherently for their depictive effect and those whose value is dependent on their effect on other objects. The former it treats as expressive "pictorial, graphic, or sculptural features," and the latter it treats as "utilitarian aspects."109 Inherently valuable design elements alone may be treated as purely expressive features of a work. Elements that are dependently valuable for their ability to affect the perception of another object are (at least partly) functional, because they do not exist merely to portray their own appearance or convey information. For garments, this dependent visual utility represents an additional way in which aspects of garment design can be utilitarian. In addition to the mechanical utility related to use, warmth, and modesty, garments have additional utility under the copyright statute when they incorporate design features that influence the wearer's appearance. ${ }^{110}$

Consider how different sorts of visual figures might be incorporated into the design of a garment. On the one hand, a drawing of a cartoon character on a t-shirt is inherently valuable. It is produced and consumed for the rep-

$107 \quad 17$ U.S.C. $\$ 101$ (emphasis added).

108 See Varsity Brands, Inc. v. Star Athletica, LLC, 799 F.3d 468, 489-90 (6th Cir. 2015). Conveying information and portraying appearances are characteristic aspects of copyrightable authorship. See generally Buccafusco, supra note 44; Fromer, supra note 63.

10917 U.S.C. $\$ 101$.

110 Cf. Jovani Fashion, Ltd. v. Fiesta Fashions, 500 F. App'x 42, 44-45 (2d Cir. 2012) (observing that a prom dress can function as such only when it can "cover the body in a particularly attractive way for [a] special occasion"); Elastic Wonder, Inc. v. Posey, 179 F. Supp. 3d 307, 317 (S.D.N.Y. 2016) ("It is the functional purpose of covering the body in an attractive and comfortable way that motivates the designs of fittings of certain shapes, and the utilitarian function of the leggings as clothing is primary over the ornamental aspect."); Fan, supra note 10 , at 1 . 
resentation it provides. ${ }^{111}$ The drawing of the character plays the same role and has the same effect whether it is on a piece of paper, a digital device screen, or a garment. On the other hand are useful article designs that are primarily dependently valuable. They produce value when brought into appropriate relationships with other objects, and in terms of their effects on those objects: making them look bigger, smaller, different, or better. Camouflage offers an ideal example of designs at this end of the spectrum, of those having dependent value. The design of a camouflage pattern achieves its value when it is placed in an appropriate environment. When it is, the pattern works: it functions to cloak the person or object that it covers. ${ }^{112}$ Consider, by comparison, the two camouflage patterns in Figure 4. The camouflage pattern on the left was worn by soldiers in the U.S. Army deployed in Afghanistan to cloak them well against their surroundings, whereas the camouflage pattern on the right, worn by North Korean soldiers, does not cloak them, but if anything, makes them easier to see.
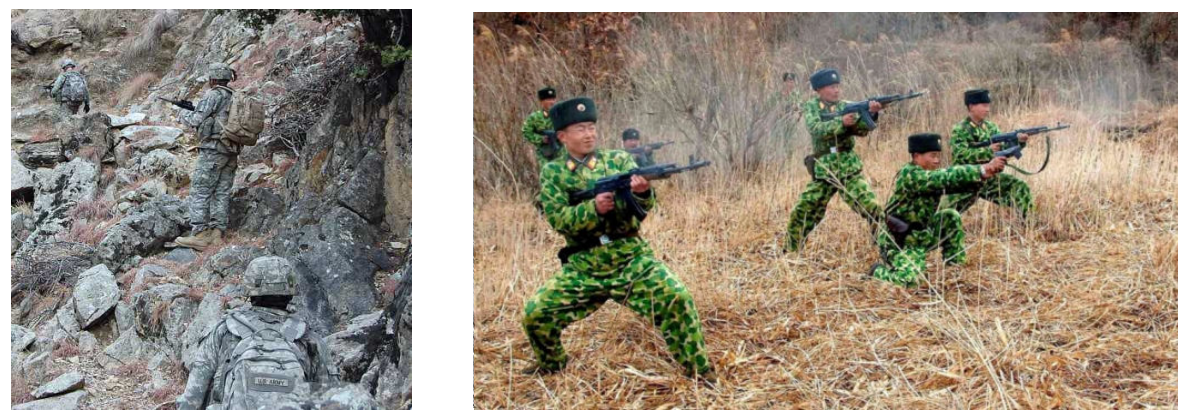

Figure 4: Effective and Ineffective Camouflage ${ }^{113}$

When a design element, like an effective camouflage pattern, alters the way another object appears, that is, when it works in relation to some other

111 Recall that paintings and many other visual designs such as drawings and sculptures will almost never be properly categorized as useful articles in the first instance because they lack "intrinsic utilitarian function that is not merely to portray the appearance of the article or to convey information.” 17 U.S.C. $§ 101$; supra Section II.B. They are therefore not useful articles subject, in the first instance, to separability analysis of their features. Even if for some reason they were, we would likely conclude for much the same reason that most drawings, paintings, and sculptures are inherently valuable, because they are produced and consumed for the representations they provide, much like a sports team's logo on a t-shirt. 112 See, e.g., Isla Forsyth, Subversive Patterning: The Surficial Qualities of Camouflage, 45 Env't \& PLAnning 1037 (2013). As with the painting, this is not the only value of camouflage. Camouflage is regularly incorporated into items with no intention of masking their appearance. Yet this does not undermine the fact that camouflage is in many cases produced and consumed for the effect it has on objects.

113 The figure on the left can be found in Army Selects New Camouflage for Afghanistan, SpACEWAR (Feb. 24, 2010), http://www.spacewar.com/reports/Army_Selects_New_Camou flage_For_Afghanistan_999.html, whereas the figure on the right can be found in Brian Ashcraft, North Korean Camo Actually Isn't That Awful, Kotaku (Oct. 31, 2013), http:// kotaku.com/north-korean-camo-actually-isnt-that-awful-1455805558. 
object, that design element should be treated as utilitarian as a matter of copyright law. ${ }^{114}$ That is, the design element is "not merely . . portray[ing] the appearance of the article or . . convey[ing] information."115 Only if a design or an aspect of design exists merely to portray its own appearance should it be treated by copyright law as purely expressive. ${ }^{116}$ One such example would be an image of a character, such as Mickey Mouse, printed on a tshirt. The character exists merely to portray its own appearance. The prior example of a paisley print on a necktie might also satisfy this requirement.

Nor is a design element, like an effective camouflage pattern, which alters the way another object appears, "merely . . . convey[ing] information." 117 That is, one might argue that the design element is conveying false information, such as a wearer's absence or invisibility in the case of an effective camouflage garment design being worn. And furthermore, in this vein, false information is as much information as accurate information. Even if it is the case that it is false, or inaccurate, information is information-something that runs contrary to some understandings of "information"118_these design elements do not "merely" convey information. They act dependently by being used on some external element to make it appear differently. That is distinct from the effect of a book comprising only lies presented as truth, which one might understand to "merely . . convey information" (assuming one construes "information" broadly). Any design element being used to change the appearance of something external to it, however, does more than just convey information by directly affecting the appearance of that external thing. ${ }^{119}$

114 Cf. Fulmer v. United States, 103 F. Supp. 1021 (Ct. Cl. 1952) (finding no copyright infringement when the U.S. government produced camouflage parachutes from the plaintiff's design showing top and side views of a similar parachute because finding otherwise would be akin to conferring unwarranted patent protection), cited in Mazer v. Stein, 347 U.S. 201, 217 n.39 (1954).

\section{U.S.C. $\$ 101$.}

116 See id. ("A 'useful article' is an article having an intrinsic utilitarian function that is not merely to portray the appearance of the article or to convey information. An article that is normally a part of a useful article is considered a 'useful article.'”).

117 Id

118 For example, one dictionary defines "information" as having multiple senses, including "facts, data," which would seem to require accuracy, and "the communication or reception of knowledge or intelligence," which might be understood more broadly to not require accuracy. Information, MERRIAM-WEBSTER, http://www.merriam-webster.com/dictionary/information (last visited Oct. 16, 2017).

119 The suggestion that graphic visual designs attached to a garment "convey information" rather than "portray [an] appearance" is an unnatural reading of the statutory text. If, for example, a designer printed a brand name or other textual material on a garment, the text might accurately be understood as conveying information. But one does not typically refer to visual depictions as conveying information; instead, they portray appearances. So, when a claimed design such as a camouflage pattern is essentially a matter of pictorial or graphic patterns or images, we think it makes more sense to ask whether these patterns or images merely portray the appearance of the article. 
In light of this discussion, we wish to respond to two lines of argument that might be raised to challenge our reading of the Copyright Act: the claim by some courts and scholars that two-dimensional design features are always nonfunctional, which the Supreme Court recently rejected, and the claim that our interpretation of the Act would treat paintings and other works of fine art as uncopyrightable because they "function" to decorate a room. We also propose that functionality ought to be assessed through the lens of both expert and consumer views.

\section{When Two-Dimensional Designs Are Functional and When They Are Not}

It is important to note that expressive techniques that affect the perception of the wearer-and are thus also functional-include both three-dimensional design choices involving the shape and cut of garments as well as twodimensional design choices involving shapes, colors, and patterns. This is essential because some courts and scholars have often reflexively treated twodimensional fabric designs as nonfunctional. ${ }^{120}$ Yet both two- and threedimensional design features will often be utilitarian in nature. As discussed above, camouflage offers an obvious example of a functional two-dimensional pattern. ${ }^{121}$ If the developer of a new camouflage pattern desires intellectual property protection, she must look to the patent system, as some camouflage designers (including the U.S. military itself) have done. ${ }^{122}$ Highvisibility fabrics or patterns are also functional, even though they are twodimensional. And the techniques discussed above in Part I use two-dimen-

120 See Galiano v. Harrah's Operating Co., 416 F.3d 411, 419 (5th Cir. 2005); 1 MeLville B. Nimmer \& David Nimmer, Nimmer on Copyright § 2.08[B][3] (rev. ed. 2017); 2 PATRY, supra note $14, \S 3: 151$.

121 See supra text accompanying note 113; cf. Fulmer v. United States, 103 F. Supp. 1021 (Ct. Cl. 1952) (finding no copyright infringement when the U.S. government produced camouflage parachutes from the plaintiff's design showing top and side views of a similar parachute because finding otherwise would be akin to conferring unwarranted patent protection), cited in Mazer v. Stein, 347 U.S. 201, 217 n.39 (1954).

122 For a sampling of utility patents covering camouflage designs, see U.S. Patent No. 6,805,957 (issued Oct. 19, 2004) ("Camouflage U.S. Marine Corps Utility Uniform: Pattern, Fabric, and Design”); U.S. Patent No. 6,499,141 (issued Dec. 31, 2002) ("Multidimensional Camouflage Outer Wear Garment System”); U.S. Patent No. 5,445,863 (issued Aug. 29, 1995) ("Camouflage Material"); U.S. Patent No. 4,931,320 (issued June 5, 1990) ("Camouflage Construction”); U.S. Patent No. 4,656,065 (issued Apr. 7, 1987) ("Bark Camouflage Cloth and Outer Garments"); U.S. Patent No. 4,576,904 (issued Mar. 18, 1986) ("Method for Developing Natural Camouflage Patterns") (assigned to the United States of America as represented by the Secretary of the Army); U.S. Patent No. 3,069,796 (issued Dec. 25, 1962) ("Camouflage Material"). For a sampling of design patents covering camouflage designs, see U.S. Patent No. D700,440 (issued Mar. 4, 2014) (“Camouflage Pattern”); U.S. Patent No. D685,999 (issued July 16, 2013) ("Sheet Material with Camouflage Pattern"); U.S. Patent No. D670,058 (issued Oct. 30, 2012) ("Combined Boot and Glove Dryer"); U.S. Patent No. D615,762 (issued May 18, 2010) ("Substrate with Camouflage Pattern”); U.S. Patent No. D560,915 (issued Feb. 5, 2008) ("Substrate with Camouflage Pattern"). 
sional patterns in similar ways, by altering how the viewer sees the clothed person. ${ }^{123}$

As the Supreme Court recently emphasized in Star Athletica, the Copyright Act clearly anticipates that two-dimensional designs can be functional when it refers to "pictorial, graphic, or sculptural features" that are inseparable from utilitarian aspects of the design. ${ }^{124}$ The first two objects in this list, pictorial and graphic features, are, in fact, two-dimensional design techniques. The statutory scheme thus makes clear that two-dimensional works and features, and not only three-dimensional works and features, can be utilitarian. ${ }^{125}$ By stating that "pictorial, graphic, or sculptural work[s]" can be "useful article[s]," rather than limiting the statutory text to "sculptural works," 126 it is apparent that Congress recognized that both two- and threedimensional works can be utilitarian. Similarly, by indicating that "pictorial, graphic, or sculptural features" might be inseparable from "utilitarian aspects" of the design, rather than just referring to "sculptural features,"127 the copyright statute signifies that both two- and three-dimensional features can be utilitarian. ${ }^{128}$

As a matter of both logic and experience, two-dimensional designs or design features can be functional when they operate to influence the way another object is perceived. But this does not mean that all two-dimensional designs are necessarily functional because they may happen to affect how other objects around them appear. Seen in this light, the Sixth Circuit's concern in its opinion in Star Athletica that recognizing this aspect of the utility of garment designs would deny protection to a Mondrian painting-on the basis that "Mondrian's painting would be unprotectable because the painting decorates the room in which it hangs" ${ }^{29}$ —is misplaced.

First, unlike the design of a garment, a painting is a "pictorial, graphic, [or] sculptural work," but is not a "useful article" as discussed above, ${ }^{130}$ because it has no "intrinsic utilitarian function that is not merely to portray the appearance of the article or to convey information."131 A Mondrian painting merely portrays its own appearance. It was designed and is con-

123 Cf. Marchese, supra note 2, at 408 (applying another framework to make the case that two-dimensional design features that affect the perception of the wearer only when worn are not truly two-dimensional features).

124 Star Athletica, L.L.C. v. Varsity Brands, Inc., 137 S. Ct. 1002, 1009 (2017) (rejecting "[t]his argument $[\mathrm{a}] \mathrm{s}$ inconsistent with the text of $\S 101 ")$.

125 Id. (citing 17 U.S.C. \$ 101 (2012)).

12617 U.S.C. $\$ 101$.

127 Id.

128 Star Athletica, 137 S. Ct. at 1009.

129 Varsity Brands, Inc. v. Star Athletica, LLC, 799 F.3d 468, 490 (6th Cir. 2015).

130 See supra Section II.B.

13117 U.S.C. $\$ 101$; see supra Section II.B (discussing why paintings are almost never useful articles as per the statutory language). 
sumed for its inherent value as a picture. For that reason, its copyrightability would never turn on statutory separability analysis. ${ }^{132}$

Consider, by contrast, trompe l'oeil design techniques, which can be used to make a room look bigger. ${ }^{133}$ As depicted in Figure 5, the components of a design that trick the eye into thinking that the ceilings are higher might mean that this sort of painting is the rare one that is a useful article. That is, such a painting should arguably not be treated like the Mondrian painting because it has "an intrinsic utilitarian function that is not merely to portray the appearance of the [painting] or to convey information." ${ }^{34}$ Aspects of the design that produce an altered visual effect, such as the use of foreshortening and a vanishing point, are properly treated as utilitarian. ${ }^{135}$ As the

132 See Lanard Toys Ltd. v. Novelty, Inc., 375 F. App’x 705, 715 (9th Cir. 2010) (“[A previous] court rightly recognized that inspiring imagination should not make an object 'useful.' Paintings and other pieces of pure art (to which Congress clearly extended copyright) have similar imagination-stoking 'uses' that would bring them within the 'useful article' exception if 'use' were defined so broadly. That approach 'would have the "useful article" exception swallow the general rule."” (quoting Gay Toys, Inc. v. Buddy L Corp., 703 F.2d 970, 973 (6th Cir. 1983))); Gay Toys, 703 F.2d at 973 (observing that a painting "has no intrinsic utilitarian function"); Flag Fables, Inc. v. Jean Ann's Country Flags \& Crafts, Inc., 730 F. Supp. 1165, 1184 n.7 (D. Mass. 1989) (rejecting the argument that "a painting would be a useful article because it has various utilitarian elements, including a frame, a means for attaching the canvas to the frame, and a wire by which to hang it on a wall"). Even if the painting were subjected to a separability analysis, however, for the same reason, the painting would be separable from any utilitarian aspects. Recall that the separability analysis would require the court to categorize components of the painting's design as purely expressive, purely functional, or dual-nature. Because virtually all of the features of the design operate solely to portray the painting's appearance, they should be treated as purely expressive and, thus, copyrightable if original. Merely because the painting may happen to have "really tied [a] room together," The Big Lebowski (Gramercy Pictures 1998), that does not magically make aspects of the painting (or the entire painting) utilitarian. The painting might look good in a room, but the object of the painting is merely to portray its own appearance. What painters create and what consumers value in a painting typically revolves around the intrinsic visual merits of the painting as such. These aspects of the painting portray their own appearance and are not utilitarian as a matter of the Copyright Act.

133 See generally Sybille Ebert-Schifferer et al., Deceptions and Illusions: Five Centuries of Trompe L'Oeil Painting (2002).

13417 U.S.C. $\$ 101$.

135 Cf. Marchese, supra note 2, at 407 (analogizing trompe l'oeil design techniques to fashion design aspects that affect the perception of the wearer). We think that the dependent visual effect of influencing the perception of the wearer's body and a situation in which a designer included a picture of Spock from Star Trek on a t-shirt in order to make viewers think that the shirt's wearer is smart and rational are distinct scenarios for our purposes. First, note that affecting the perception of the wearer's body is a direct and firstorder effect, while affecting viewers' cognitions or judgments is an indirect and secondorder effect. Cf. Baker v. Selden, 101 U.S. 99, 102 (1879) ("A treatise on ... the mode of drawing lines to produce the effect of perspective . . . would be the subject of copyright; but no one would contend that the copyright of the treatise would give the exclusive right to the art or manufacture described therein."). In addition, copyright law's prohibition on protection for inseparable functional features of useful articles is intended to channel fea- 
Supreme Court long ago recognized in Baker v. Selden, ${ }^{136}$ "[a] treatise on . . . the mode of drawing lines to produce the effect of perspective . . . would be the subject of copyright; but no one would contend that the copyright of the treatise would give the exclusive right to the art or manufacture described therein." 137 Copyright law cannot be used to grant exclusive rights to particular techniques of design when those techniques have more than purely depictive ends.

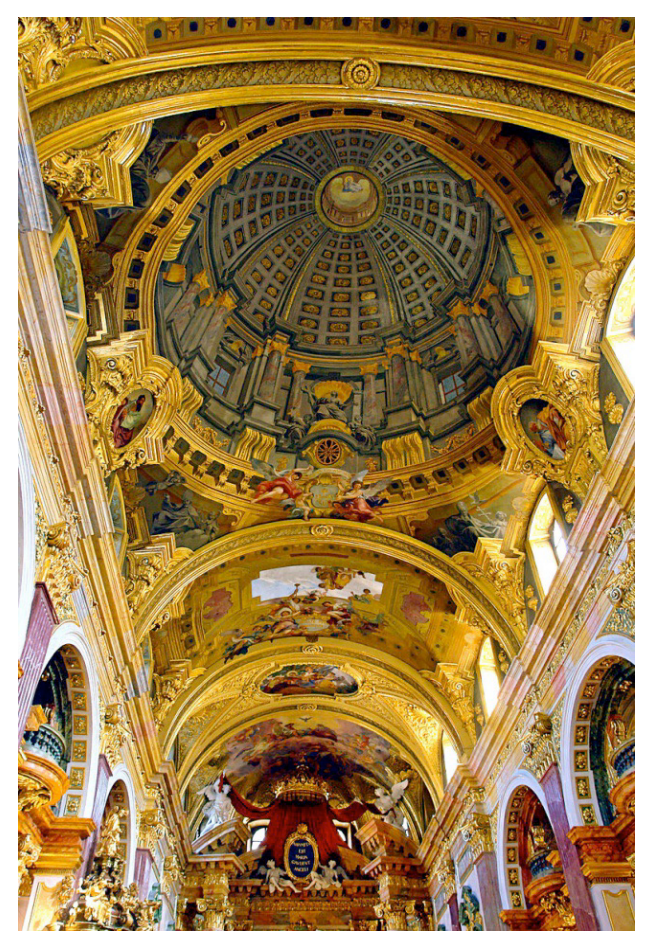

Figure 5: Andrea Pozzo, Fresco with Trompe L'Oeil Dome Painted on Low Vaulting, Jesuit Church, Vienna, Austria (1703)

tures potentially covered by patent law there, where they will be suitably screened for protectability. See supra Section II.A (discussing the separate spheres of patent and copyright laws). A t-shirt with a design that causes its wearer to appear smarter or more rational is not at all the sort of useful item that patent law protects. See supra Section II.A. Therefore, copyright law's own definition of functionality - "an intrinsic utilitarian function that is not merely to portray the appearance of the article or to convey information," 17 U.S.C. $\S 101$-would not filter from protectability such a t-shirt design. Finally, the competitive costs to other designers are substantially different in the two situations, because of the number of available options for achieving one or the other. Techniques for affecting the perception of the wearer's body are severely limited by the physical nature of bodies and the physical features of human vision. But there are so many more ways to achieve the same mental effect. One might, instead of wearing a shirt that depicted Spock, for example, wear a shirt that said Oxford or Cambridge.

136101 U.S. 99 (1879).

137 Id. at 102. 


\section{How to Determine Functionality: Experts and Consumers}

Returning to two-dimensional features of garment design, the Copyright Act treats these aspects of garment design that influence the perception of a wearer's body as utilitarian aspects of a useful article, even if they are also expressive features. Figuring out, in any given case, whether a particular feature has this effect may depend on whom you ask. Whether a design feature is expressive, functional, or both can sometimes turn on which audience is surveyed-be it garment designers, consumers of particular garment designs, or fashion critics. ${ }^{138}$ But this sort of challenge is a standard feature of copyright jurisprudence, and it does not necessarily prevent the rational application of the law or hinder Congress's goals. ${ }^{139}$

One of us has previously written about audience choices in assessing infringement. ${ }^{140}$ As discussed there, who decides whether a defendant's product is too similar to a plaintiff's can affect the answer. ${ }^{141}$ We propose that in intellectual property infringement cases, both experts and consumers are the right audiences to be evaluating that similarity. ${ }^{142}$ That is, to infringe, both experts and consumers must regard a defendant's work as too similar to the plaintiff's. The reason is intimately tied to why protection is offered in the first instance. Copyright law exists to encourage the creation of works that are artistic contributions and to protect them from being copied in ways that harm the market for them. ${ }^{143}$ Therefore, it is imperative to ensure that a defendant's work appears similar enough to consumers that they would substitute the defendant's for the plaintiff's, thereby cutting into the plaintiff's incentive to create, and that the work also appears too similar to experts in the field to ensure that the defendant's work has not made a sufficient artistic contribution beyond the plaintiff's. ${ }^{144}$

For similar reasons, the useful articles doctrine should incorporate both of these two audiences as the relevant ones for determining the treatment of design features: A design feature should be considered solely expressive (and nonfunctional) only if both experts and consumers see it as a nonfunctional feature. Both groups are key to assessing the nonfunctionality of design features, for much the same reasons that they are both key in assessing infringement. For instance, a garment designer might claim to have had no intent to produce a dress with a pattern that is slimming, but consumers buy the dress

138 See Horn \& Gurel, supra note 12, at 311 ("[D] esigners impart their individual imprints to the products of their craft and in doing so reveal a part of their nature, their ideals, values, thoughts, and emotions. The product in turn evokes a similar or perhaps a widely different range of feelings and emotions in the observer.").

139 See generally Jeanne C. Fromer \& Mark A. Lemley, The Audience in Intellectual Property Infringement, 112 MicH. L. Rev. 1251 (2014). Similar issues arise with respect to questions of originality, infringement, and fair use, for example. Id.

140 See id.

141 See id.

142 See id. at 1251-52.

143 See id. at 1267-68.

144 See id. at 1268. 
for precisely that reason. In such a case, the consumers' treatment of the garment should control. Allowing designers to dictate the treatment of their works by authorial fiat would allow them too much latitude to claim that their designs are nonfunctional even though they clearly are and are purchased for that reason. Conversely, however, consumers may not sufficiently understand the nature of design such that they do not realize that or how certain features are, in fact, functional. For example, a consumer may try on a dress and think that its design looks beautiful without understanding design features that were incorporated to make the dress look good on wearers' bodies. In such a case, design experts can testify that certain design features have known effects, and courts can inquire into the designer's creative process to determine whether features were added in such a way as to influence the appearance of the wearer. ${ }^{145}$ Thus, credible evidence that the designer intended for the features to be functional would render them as such even if consumers did not understand or appreciate their functionality.

\section{Fashion's Function in the Courts}

That features affecting the perception of the wearer are functional is, we think, the point that courts in the Second Circuit have made, perhaps less clearly than desirable, in a line of cases identifying a utilitarian "decorative function" in garment design. For example, in Whimsicality, Inc. v. Rubie's Costume Co., ${ }^{146}$ a case concerning the copyrightability of various costume designs, the Second Circuit explained that while conceptually separable features of garment designs could, in theory, receive copyright protection, most aspects of garment design would not meet this standard because "the very decorative elements that stand out [are] intrinsic to the decorative function of the clothing." 147 That is, the particular features of the garment for which the designer claims protection are likely also to be ones that affect how the wearer is perceived.

Similarly, in Jovani Fashion, Ltd. v. Cinderella Divine, Inc. ${ }^{148}$ the Southern District of New York explained that the sequins and crystals on the bodice of the prom dress at issue, the horizontally ruched-satin fabric on the waistband, and the layers of tulle in the skirt were "plainly fashioned to fit the specific needs of a prom dress." 149 These aspects of the prom dress, while attractive on their own, also contributed to the dress's "utilitarian function of enhancing the wearer's attractiveness." 150 The Second Circuit, upholding the judgment, agreed, emphasizing that these garment features are not separable

145 Cf., e.g., Brandir Int'l, Inc. v. Cascade Pac. Lumber Co., 834 F.2d 1142, 1145 (2d Cir.

1987) (holding that "where design elements can be identified as reflecting the designer's artistic judgment exercised independently of functional influences, conceptual separability exists").

146891 F.2d 452 (2d Cir. 1989).

147 Id. at 455.

148808 F. Supp. 2d 542 (S.D.N.Y. 2011).

$149 I d$. at 550.

$150 I d$. 
"pictorial, graphic, or sculptural features"151 because "the [physical or conceptual] removal of these items would certainly adversely affect the garment's ability to function as a prom dress, a garment specifically meant to cover the body in an attractive way for a special occasion." 152

These opinions correctly recognize that garments do not typically exist merely to look attractive in their own right but also to make those who wear them look more attractive. This "decorative function" is one we think is better referred to as having "dependent value," by which we mean value dependent on use in relation to another object, or more specifically in the context of fashion, features that affect the perception of the wearer. ${ }^{153}$ Moreover, these opinions treat aspects of garment design that affect how the wearer looks as appropriately placed on the "utilitarian aspects" side of the expressive/functional ledger when determining conceptual separability, even if they may also fall on the other side as "pictorial, graphic, or sculptural features."154 Indeed, many features of garment design will have this dual nature. They will be both expressive features and simultaneously utilitarian aspects of the garment. This is consistent with the definition of "useful articles" in $\S 101$, which recognizes that design features may perform both expressive and functional roles. ${ }^{155}$

The opinions emerging from the Second Circuit courts differ substantially from the recent Sixth Circuit opinion in Star Athletica. ${ }^{156}$ Analyzing the cheerleading uniforms at issue, the court attempted to categorize the components of the uniform designs as expressive "pictorial, graphic, or sculptural features" or functional utilitarian aspects. ${ }^{157}$ In so doing, however, the court made no allowance for the possibility that a component could be dualnature-that it could play both expressive and functional roles in the design. And the court explicitly declined to adopt the Second Circuit's account of the "decorative function" of fashion, because it feared that doing so would commit it to holding an artistic painting uncopyrightable. ${ }^{158}$ According to

15117 U.S.C. $\$ 101$ (2012).

152 Jovani Fashion, Ltd. v. Fiesta Fashions, 500 F. App'x 42, 44 (2d Cir. 2012); cf. Kieselstein-Cord v. Accessories by Pearl, Inc., 632 F.2d 989, 993 (2d Cir. 1980) (recognizing that the belt buckles at issue "include decorative features that serve an aesthetic as well as a utilitarian purpose"); Elastic Wonder, Inc. v. Posey, 179 F. Supp. 3d 307, 317 (S.D.N.Y. 2016) ("It is the functional purpose of covering the body in an attractive and comfortable way that motivates the designs of fittings of certain shapes, and the utilitarian function of the leggings as clothing is primary over the ornamental aspect.").

153 Giovanna Marchese criticizes the Jovani decision and its "decorative function" terminology for "denying protection to an aesthetic work that has a concomitant utilitarian function . . rather than advancing a convincing legal argument." Marchese, supra note 2, at 402.

154 Cf. id. at 399-401 (suggesting a similar interpretation of Jovani as one of multiple possibilities).

155 See supra Section II.A.

156 Varsity Brands, Inc. v. Star Athletica, LLC, 799 F.3d 468 (6th Cir. 2015).

157 Id. at 490.

$158 I d$. ("Such a holding would render nearly all artwork unprotectable. Under this theory of functionality, Mondrian's painting would be unprotectable because the painting 
the Sixth Circuit, the stripes, chevrons, zigzags, and color-blocking on the uniforms were purely expressive and separable from the uniforms' functions of covering the body, sweat wicking, and enabling athletic performance. ${ }^{159}$ We explain how our approach to fashion's function would handle Star Athletica's fashion design elements in Part III.

\section{The Unprotectability of Dual-Nature Design Features in Copyright Law}

Recall from above that the key feature of the useful articles doctrine involves the separability of expressive features of a work from its functional aspects. If a work exhibits purely expressive features, those features may be separable from the work's function. Dual-nature design features, however, should not be protected by copyright law. These features cannot be treated as separable under any recognized test for separability, because the same design aspects play both expressive and functional roles simultaneously. When a claimed aspect of a design is both visually appealing and at the same time utilitarian it makes no sense to say that the visually appealing nature of the aspect "can be identified separately from, and [be] capable of existing independently of" the functional nature of the aspect. ${ }^{160}$ The curve of the hood of a Corvette Stingray both makes the car look beautiful and affects its aerodynamics. ${ }^{161}$ In drafting the useful articles doctrine, Congress rejected copyright protection for these sorts of dual-nature designs to prevent copyright law from being used as a form of backdoor patent protection. ${ }^{162}$

In the myriad of cases involving separability, we have not located any court decision-neither by the Supreme Court nor by any other federal court-that has expressly found an element of a useful article to possess this dual nature and also to be separable and therefore copyrightable. As the Eleventh Circuit has explained, "functional components of useful articles, no matter how artistically designed, have generally been denied copyright protection" as inseparable. ${ }^{163}$ Consider just a few examples: The Ninth Circuit has held that the distinctive shape of a hookah water container is also functional and therefore not separable. ${ }^{164}$ The Eleventh Circuit has found all components of a light fixture to be uncopyrightable because "the expressive

decorates the room in which it hangs. But paintings are copyrightable." (citing Gay Toys, Inc. v. Buddy L Corp., 703 F.2d 970, 973 (6th Cir. 1983))). For our criticism of this reasoning, see supra text accompanying notes 129-132.

159 Star Athletica, 799 F.3d at 492 ("We therefore conclude the arrangement of stripes, chevrons, color blocks, and zigzags are 'wholly unnecessary to the performance of' the garment's ability to cover the body, permit free movement, and wick moisture." (quoting Carol Barnhart Inc. v. Econ. Cover Corp., 773 F.2d 411, 419 (2d Cir. 1985))).

16017 U.S.C. $\$ 101$ (2012).

161 See Steve Temple, 2014 Corvette C4 Stingray-Like a Knife, Super Chevy (Oct. 2, 2013), http://www.superchevy.com/features/1309-2014-corvette-c7-stingray-like-a-knife.

162 See supra Part I.

163 Norris Indus., Inc. v. Int'l Tel. \& Tel. Corp., 696 F.2d 918, 924 (11th Cir. 1983) (listing physically separable elements, however, as an exception).

164 See Inhale, Inc. v. Starbuzz Tobacco, Inc., 755 F.3d 1038 (9th Cir. 2014). 
aspects of the light fixtures are also functional components of the utilitarian articles." 165 The Second Circuit has held that "the form of [a bicycle] rack is influenced in significant measure by utilitarian concerns and thus any aesthetic elements cannot be said to be conceptually separable from the utilitarian elements." 166 A Colorado district court has held that a lifelike model of a human skeleton designed to teach anatomy is functional and that any expressive features are not separable. ${ }^{167}$ If these dual-nature elements of useful articles receive protection, it must be through the patent regime. ${ }^{168}$

One can appreciate the futility of a claim to copyrightability of dualnature design features when one tries to imagine the aspects of their designs to which copyright might attach. As the Copyright Act explains, copyright protection for a useful article extends only "to the extent" of the separable expressive features of the design. ${ }^{169}$ Thus, while the separable expressive features may receive protection, copyright will never cover the utilitarian aspects of the design. ${ }^{170}$ As a matter of logic, the Copyright Act cannot both protect the expressive features of the uniforms and preserve from protection their functional aspects when those expressive features and functional aspects are one and the same. ${ }^{171}$

165 Progressive Lighting, Inc. v. Lowe's Home Ctrs., Inc., 549 F. App’x 913, 921 (11th Cir. 2013) (per curiam).

166 Brandir Int'l, Inc. v. Cascade Pac. Lumber Co., 834 F.2d 1142, 1147 (2d Cir. 1987).

167 See Zahourek Sys., Inc. v. Balanced Body Univ., LLC, No. 13-cv-01812, 2016 WL 1377165 (D. Colo. Apr. 7, 2016).

168 There are, by contrast, many cases in which courts hold that a feature of a useful article is expressive, but not functional, and also separable (and therefore copyrightable). See, e.g., Mazer v. Stein, 347 U.S. 201, 201 (1954) (holding an expressive dancer statuette to be separable from a functional lamp); Home Legend, LLC v. Mannington Mills, Inc., 784 F.3d 1404, 1404-05 (11th Cir. 2015) (holding that a decorative layer featuring two-dimensional artwork between a core board and a transparent overlay in laminate wood flooring was expressive, separable, and copyrightable); Pivot Point Int'l, Inc. v. Charlene Prods., Inc., 372 F.3d 913, 914 (7th Cir. 2004) (determining that specific facial features on a mannequin used as a hair stand and makeup model were expressive, and not functional, choices and were therefore separable and copyrightable); Kieselstein-Cord v. Accessories by Pearl, Inc., 632 F.2d 989, 990 (2d Cir. 1980) (holding that the expressive, nonfunctional ornamentation on belt buckles is conceptually separable from the functional aspects of the belt buckle); DC Comics v. Towle, 989 F. Supp. 2d 948, 970 (C.D. Cal. 2013) (“[T] he design elements of the two Batmobiles at issue here are conceptually separable from their underlying car. In particular, the 1989 Batmobile's entire frame, consisting of the rear exaggerated, sculpted bat-fin and the mandibular front, is an artistic feature that can stand on its own without the underlying vehicle. The underlying vehicle would still be a car without the exaggerated bat features."); Lego A/S v. Best-Lock Constr. Toys, Inc., 874 F. Supp. 2d 75, 99 (D. Conn. 2012) ("If the [Lego] minifigures' capacity to attach to other toys is functional, while their capacity to inspire imagination or play are not, then the drawings on the face and torso are clearly conceptually separable ....").

16917 U.S.C. $\$ 101$ (2012).

170 These will always remain free to copy unless protected by another intellectual property regime such as patent law. See Buccafusco \& Lemley, supra note 6.

171 The Supreme Court does not say otherwise in Star Athletica, but merely assumes that the design elements at issue are expressive and not functional. See infra Part III. For an 
When the same aspects of the designs are simultaneously expressive and functional, courts need not inquire further into their separability. The expressive and functional aspects are inherently inseparable, and thus the designs are unprotectable as a matter of law. As we demonstrate in the case study of cheerleading uniforms below, the vast majority of components of garment design should fall into the dual-nature category and should thus be screened out of copyright protection by the useful articles doctrine, if not by other copyrightability doctrines such as merger. Two- and three-dimensional aspects of a garment design that influence the perception of the wearer should always fall into the dual-nature category. Because the useful articles doctrine should always screen out dual-nature design features as inherently inseparable, they should never receive copyright protection. This result is consistent with Congress's desire that copyright law is not the proper home for garment design. ${ }^{172}$ Only if a garment exhibits purely expressive features and only if those features are also separable from the rest of the garment should the design of an article of clothing ever receive copyright. This should be a rare occurrence. ${ }^{173}$

\section{The Conceptual Shortcomings of $S_{T A R} A t h l e t i c a$}

The account presented in Part II best comports with the Copyright Act's useful articles doctrine as Congress drafted it and the policy goals undergirding it. Recently, the U.S. Supreme Court had an opportunity to affirm these principles in Star Athletica, L.L.C. v. Varsity Brands, Inc. ${ }^{174}$ Instead, the Court charted an entirely new path through copyright law, upsetting decades of lower court precedents and altering the nature of copyright's functionality screening. Here we attempt to explain what the Court did and how it went so wrong. We also discuss how our account of fashion's function should still matter for copyright validity and infringement even if its role in the useful articles doctrine is now different.

elaboration on this point with a comparison to copyright law's merger doctrine, see supra note 85 .

172 H.R. REP. No. 94-1476, at 55 (1976), reprinted in 1976 U.S.C.C.A.N. 5659, 5668 ("Unless the shape of an automobile, airplane, ladies' dress, food processor, television set, or any other industrial product contains some element that, physically or conceptually, can be identified as separable from the utilitarian aspects of that article, the design would not be copyrighted ....").

173 Costumes are potentially copyrightable garment designs. See, e.g., Charles E. Colman, The History and Doctrine of American Copyright Protection for Fashion Design: Managing Mazer, 7 Harv. J. Sports \& Ent. L. 151, 190-202 (2016). When a designer depicts a character or animal in a costume made to be worn by a person, there may be aspects of the character or animal design that are unrelated to any functional consideration. Design elements that are based on the need to conform the costume to the particular features of the human body, however, are functional and not protectable. See Entm't Research Grp., Inc. v. Genesis Creative Grp., Inc., 122 F.3d 1211, 1218-24 (9th Cir. 1997).

$174 \quad 137$ S. Ct. 1002 (2017). 
The case centers on the copyrightability of the cheerleading uniform designs shown in Figures 6 and 7.175 The Supreme Court held the arrangement of stripes, chevrons, zigzags, and color-blocking in the garment designs to be separable features of useful articles and potentially copyrightable. ${ }^{176}$ In light of our analysis above, we think the Supreme Court came to the wrong conclusion, after failing to recognize that the arrangement of stripes, chevrons, zigzags, and color-blocking in the garment designs at issue-like many components of clothing designs-has both expressive and utilitarian aspects.
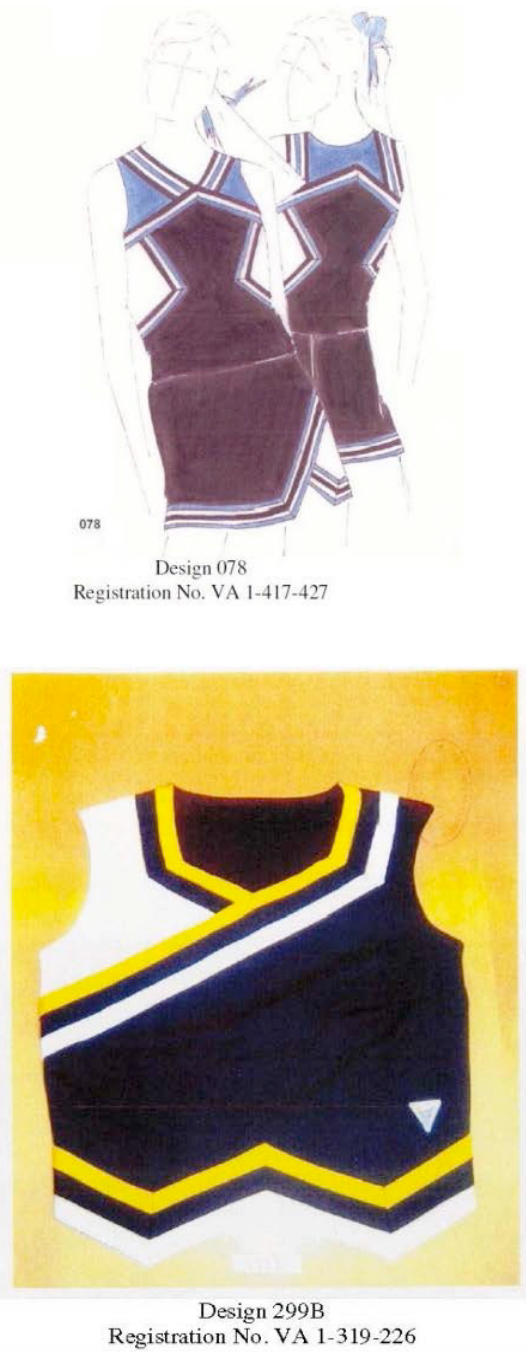
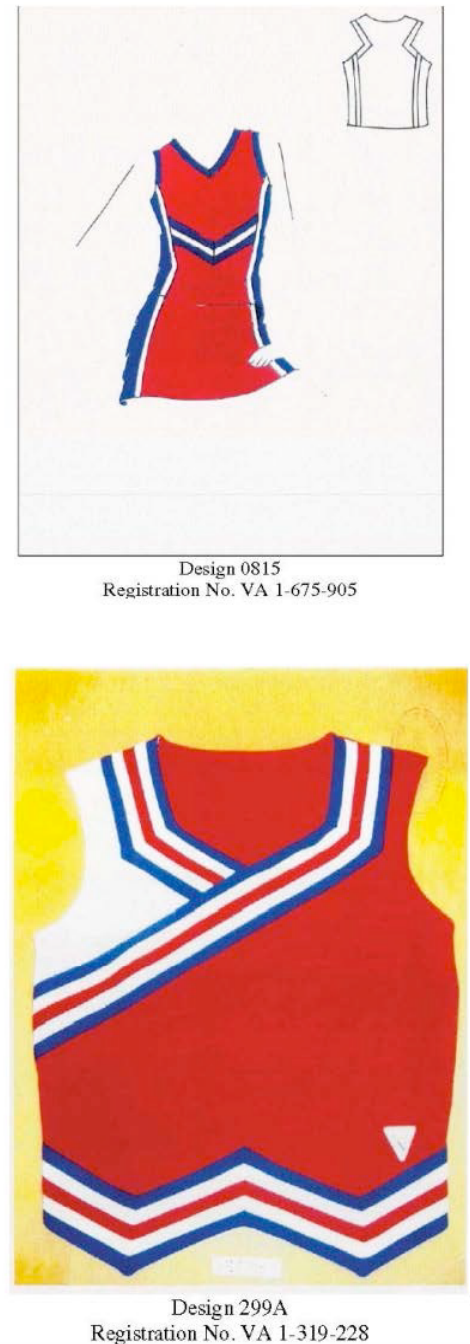

Registration No. VA 1-319-228

Figure 6: Varsity's Claimed Designs 


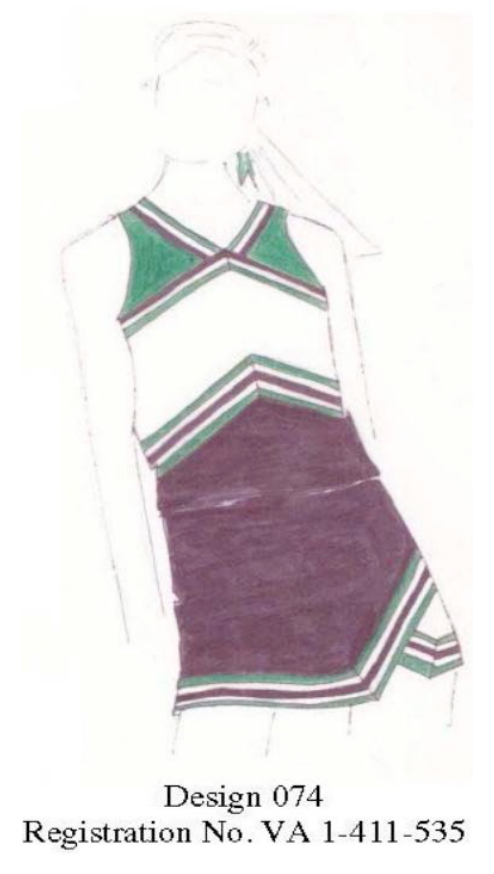

Figure 7: Varsity's Claimed Design

Varsity submitted the above designs for registration by the Copyright Office, and Varsity sued Star Athletica for producing uniforms displaying similar designs. The district court granted the defendant's summary judgment motion, ruling that the designs were not protectable because they served the function of identifying their wearers as cheerleaders. ${ }^{177}$ The Sixth Circuit Court of Appeals reversed. ${ }^{178}$ It is worth spending a moment on the Sixth Circuit's opinion because, even though we think it reached the wrong conclusion, it did so via a logical methodology. The appellate court engaged in the correct set of steps, first determining that the uniform designs were useful articles and then identifying their expressive and functional features. ${ }^{179}$ It was only in applyig this step that we think the court erred. It concluded that the only features of the uniforms that were functional were those that contributed to their mechanical use as garments, such as enabling wearers to jump and flip or cover their bodies. ${ }^{180}$ The Sixth Circuit determined that the stripes, chevrons, and color-blocking were purely expressive features and were separable from the rest of the uniforms. ${ }^{181}$ In doing so, the court

177 Id. at 1008; Varsity Brands, Inc. v. Star Athletica, LLC, No. 10-2508, 2014 WL 819422, at *9 (W.D. Tenn. Mar. 1, 2014), rev'd, 799 F.3d 468 (6th Cir. 2015).

178 Varsity Brands, Inc. v. Star Athletica, LLC, 799 F.3d 468, 471 (6th Cir. 2015).

179 See id. at $487-88$.

180 See id. at 490.

181 See id. at 491-93. 
rejected arguments based on the Second Circuit cases discussed above about the designs' decorative function. ${ }^{182}$

The Sixth Circuit understood the basics of the useful articles doctrine and its separability analysis. Its only problem was its failure to grasp that the plaintiff's designs are not purely expressive. Instead, the stripes, chevrons, zigzags, and color-blocking in the claimed designs serve a dual-nature purpose, similar to those documented in Part I. They are simultaneously both expressive and functional, serving to accentuate and elongate the cheerleader's body and make it appear curvier in particular areas. ${ }^{183}$ We detail some of these dual-nature features in light of the discussion in Part I.

In Design 078, the white patches in the color-blocked pattern help create the visual effect of curviness by creating an hourglass shape with contrast, as in Stella McCartney's dresses. ${ }^{184}$ The V-shaped neckline together with the inverted-V-shaped slit on the skirt elongates the body by exploiting the Müller-Lyer illusion. The V-shaped neckline also serves to point to the bust and elongate the neck. The color-blocking, using contrasting colors, creates contrast and draws attention to the wearer's body. The repeating stripe pattern at the neckline, bust, waist, and skirt hem draws viewers' attention from the top of the wearer's neckline all the way to the bottom of the wearer's skirt to see that part of the wearer's body as unified. ${ }^{185}$

Again, in Design 0815, Varsity employs color-blocking; this time a darker blue color along the side of the uniform to make the wearer look both more slender in certain places and curvier in others, just as in the Stella McCartney dresses. ${ }^{186}$ In addition, the V-shaped striping on the front center of the uniform serves to further accentuate the bust. The V-shaped neckline both points to the bust and elongates the neck. Designs 299A and 299B have some of the same features associated with the previous two designs, plus there is a diagonal striping, which calls attention to the body's rounded contours. Additionally, the chevron at the bottom of the uniform top is cut to display some of the belly and draw attention to it. Design 074 serves to accentuate the curves and elongate the body for many of the reasons discussed with regard to the previous designs. In addition, the color-blocking serves to highlight the bust by coloring it in white in contrast to the green above it and navy blue below it.

182 See id. at 490.

183 For a similar observation about these cheerleading uniform designs, see Marchese, supra note 2, at 412; see also id. at 379 (stating that the designs "create a trim silhouette shape of the cheerleader").

184 Giovanna Marchese likewise emphasizes that "the chevrons and stripes are arranged so that the edge of the chevron's ' $\mathrm{V}$ ' frames the cheerleader's chest," and that "[t]he panels immediately outside the ' $\mathrm{V}$ ' use colors that sharply contrast the color within the ' $\mathrm{V}$,' which creates a visual effect in the viewer of an hourglass body shape." $I d$. at 379 n.15.

185 See DeLong, supra note 9, at 229 ("Direction can be aided by repetition of similar parts, often called rhythm. Rhythm is defined as the ordered recurrence of parts that leads the eye.").

186 See supra note 21-23 and accompanying text. 
The stripes, chevrons, zigzags, and color-blocking that form the heart of Varsity's uniform designs do not merely portray their own appearance or convey information. They also influence the appearance of the uniform's wearer. These features are the reason that the designs work as appropriate designs for garments meant to emphasize the fitness, athleticism, and attractiveness of those who don them. It is no accident that Varsity here chose to design its uniforms in this fashion, and it is no accident that many cheerleading uniforms share similar design features. ${ }^{187}$ Granting copyright protection to these designs would enable Varsity to monopolize functional aspects of garments without satisfying the exacting demands of patent law. Although other designers might be free to produce cheerleading uniforms incorporating features that flatten the bust, widen the waist, and shorten the legs, we suspect that they are unlikely to find a vibrant market for such products. This is not the sort of competitive advantage that copyright law is intended to foster. ${ }^{188}$

The claimed features of Varsity's cheerleading uniform designs are perfect examples of dual-nature features. As explained in Part I, the arrangement of stripes, chevrons, zigzags, and color-blocking that make up the expressive features of Varsity's designs also serve a functional purpose: to influence how the wearer's body is perceived. The particular design features of Varsity's uniforms do not exist merely to portray their own appearance. They are not merely ornamental or arbitrarily determined in the way that a graphic of a cartoon character printed on a shirt is. They are placed where they are because of the nature of the human bodies that will wear them. The shapes, sizes, and colors of the design features look the way they do because these particular shapes, sizes, and colors will interact with wearers' bodies in particular ways. While they might be aesthetically pleasing or attractive in their own right, they also affect the actual perception of the wearers' bodies as aesthetically pleasing or attractive. ${ }^{189}$

187 It is also no accident that Varsity's designs for male cheerleaders often have different design elements from those for female cheerleaders, because the physical aspects of male and female bodies that are emphasized differ. See 2016 Varsity Spirit Fashion CataLOG 82, www.varsity.com/publications/Varsity-Spirit-Fashion-2016.html\#82.

188 See Sony Comput. Entm't, Inc. v. Connectix Corp., 203 F.3d 596, 607 (9th Cir. 2000) ("Sony understandably seeks control over the market for devices that play games Sony produces or licenses. The copyright law, however, does not confer such a monopoly."); Sega Enters. Ltd. v. Accolade, Inc., 977 F.2d 1510, 1523-24 (9th Cir. 1992) (“[A]n attempt to monopolize the market by making it impossible for others to compete runs counter to the statutory purpose of promoting creative expression.").

189 This is a different claim from the one made by Judge McKeague in his dissenting opinion in the Sixth Circuit's decision below in Star Athletica. See Varsity Brands, Inc. v. Star Athletica, LLC, 799 F.3d 468, 494-95 (6th Cir. 2015) (McKeague, J., dissenting). We are not claiming that the design features perform a signifying function to identify the wearers as cheerleaders, a "function" we think is properly conceived as "convey[ing] information," and thus not utilitarian according to the Copyright Act. 17 U.S.C. $\$ 101$ (2012). If any feature of a design that served to identify something or someone were to be treated as functional by copyright law, then no trademark could ever be copyrighted, because the point of a trademark is to identify the source of the goods to which it is affixed. Clearly, 
Unlike the Sixth Circuit, which misinterpreted what makes a design feature utilitarian or expressive, the Supreme Court thoroughly misunderstood the statute it claimed to be interpreting. Justice Thomas's majority opinion treats the separability criteria as both intellectually simple and doctrinally weak when they are, in fact, neither of these things. He first asks whether the decisionmaker can "spot some two- or three-dimensional element that appears to have pictorial, graphic, or sculptural qualities." ${ }^{190} \mathrm{He}$ describes this requirement as "not onerous," 191 as his application of the test to the uniforms proves. According to the majority, an element of a design counts as an expressive feature if it looks like something. ${ }^{192}$ As we discuss elsewhere in a commentary on the decision, "[c] onsidering that this is the area of copyright law that applies to pictorial, graphic, and sculptural works, it is impossible that the claimed works would not have some such features."193

The Supreme Court next asks whether the identified expressive feature can exist apart from the utilitarian aspects of the article. ${ }^{194}$ The Court explains that "the feature must be able to exist as its own pictorial, graphic, or sculptural work . . . once it is imagined apart from the useful article." 195 Finally, the Court indicates, "If the feature is not capable of existing as a pictorial, graphic, or sculptural work once separated from the useful article, then it was not a pictorial, graphic, or sculptural feature of that article, but rather one of its utilitarian aspects." 196 Although we do not find these statements to be entirely clear, we think that they imply that given "some [expressive] qualities that were spotted in the first step, the second step of the analysis asks whether they could be fixed in some form other than the useful article itself." 197 Or as we put it more simply elsewhere: "In effect, the majority's test for separability amounts to: Could you draw it on a sheet of paper? ${ }^{198 " ~ " H e r e, ~ b e c a u s e ~ t h e ~[u n i f o r m ~ d e s i g n s] ~ c o u l d ~ h a v e ~ b e e n, ~ a n d ~ a c t u-~}$

this is not the case. See Laura A. Heymann, Overlapping Intellectual Property Doctrines: Election of Rights Versus Selection of Remedies, 17 Stan. Tech. L. Rev. 239, 242 (2013). We argue that these design features are functional instead because they were designed to influence how the wearers' bodies were perceived.

190 Star Athletica, L.L.C. v. Varsity Brands, Inc., 137 S. Ct. 1002, 1010 (2017).

$191 I d$.

$192 I d$. at 1012 ("[O]ne can identify the decorations as features having pictorial, graphic, or sculptural qualities.”).

193 Christopher Buccafusco \& Jeanne C. Fromer, Essay, Forgetting Functionality, 166 U.

PA. L. Rev. Online 119, 121 (2017).

194 Star Athletica, 137 S. Ct. at 1010.

$195 I d$.

$196 I d$.

197 Buccafusco \& Fromer, supra note 193, at 122-24.

$198 I d$. at 122. More generously, the Court may be asking if you could draw it on a sheet of paper and it would look not entirely like the useful article as such, whatever that would be. For example, if you drew the expressive features of a shovel on a piece of paper, it would simply look identical to the shovel. 
ally were, reproduced on other (presumably non-useful) media[-in drawings-] they were separable."199

The Supreme Court has utterly failed to understand the statute and its requirement that decisionmakers identify distinct expressive and functional features of the claimed work. In its interpretation of the "ordinary, contemporary, common meaning" 200 of the statute, the Court asks whether the spotted expressive features can be "imagined apart from the useful article."201 But this is not how the statute reads. ${ }^{202}$ Instead, the statute asks whether the work's expressive features can be separated from "the utilitarian aspects of the article." 203 The difference is not trivial. The Court's statutory misreading substantially lowered the bar for claimants: Rather than distinguishing between and separating the uniform design's pictorial, graphic, and sculptural features from its utilitarian aspects, the Court only asked whether the pictorial, graphic, and sculptural features were distinct and separate from the uniform itself. Varsity could then claim the stripes, chevrons, and colorblocking because, once they were imaginatively removed from the uniform, a uniform could still exist. That is a different exercise from asking whether a design's pictorial, graphic, and sculptural features could be separated from the design's utilitarian aspects. ${ }^{204}$

Under the correct formulation of the test, the Court would have had to determine which components of the design it should treat as utilitarian aspects, something it never asked under the test it conceived for itself.

To make matters worse, the Court failed to appreciate how rigorously Congress intended copyright law to treat functionality. The Court seems to have rejected the notion that copyright law should only be used to protect a work's exclusively expressive features. ${ }^{205}$ The majority explains that the imaginatively removed feature of the work "may not be a useful article," but the majority concludes that the feature is still protectable even if "the imagined remainder [is not] a fully functioning useful article at all, much less an equally useful one." 206 This reading of the Act flips the statute on its head. Instead of copyright law protecting only solely expressive features of a work and excluding completely functional and dual-nature aspects, the Court's opinion will prevent copyright from attaching only to purely functional features of the work. ${ }^{207}$

199 Id; see Star Athletica, 137 S. Ct. at 1012. In Star Athletica, the Supreme Court officially "abandon[ed] the distinction between 'physical' and 'conceptual' separability." Id. at 1014 .

200 Star Athletica, 137 S. Ct. at 1010 (quoting Walters v. Metro. Educ. Enters., Inc., 519 U.S. 202, 207 (1997) (internal quotation marks omitted)).

$201 I d$.

202 See Buccafusco \& Fromer, supra note 193, at 122-24.

20317 U.S.C. $\$ 101$ (2012).

204 Buccafusco \& Fromer, supra note 193, at 122-24.

205 See Star Athletica, 137 S. Ct. at 1013.

206 Id. at 1013-14.

207 See Buccafusco \& Lemley, supra note 6. 
Given the Court's statutory interpretation, it never had to think carefully about the arguments we have raised above. Because the Court lowered the bar for copyright claimants to protect functional aspects of their designs, it did not significantly interrogate whether the features of the uniform designs that influenced perceptions of wearers' bodies were dual-nature. ${ }^{208}$ The Court further neglected to rely on the part of the copyright statute that explains what makes a feature utilitarian ${ }^{209}$ and which we think requires the classification of many fashion features as utilitarian and therefore inseparable and unprotectable.

Although this is a shame, it is not a complete catastrophe. The useful articles doctrine is not the only mechanism by which copyright law polices functionality, and we are sanguine that subsequent courts will utilize these tools.

For example, for the same reasons as we have articulated as to why these design features are not separable, they likely run afoul of the merger doctrine and ought to be denied protectability on that ground as well. Recall that when there are a limited number of ways to express something, the merger doctrine denies copyrightability to that expression, lest it protect the function too. ${ }^{210}$ Given the particularities of human vision and human torsos, we suspect that there are only a limited number of ways to express the functions of accentuating the cheerleader's curves, lengthening the cheerleader's torso, and so forth. There is thus good basis to deny copyrightability to these features for having merged function and expression.

In addition, when decisionmakers compare a plaintiff's work with an allegedly infringing work, copyright law demands that they filter out from their analysis aspects of the plaintiff's work that are functional. ${ }^{211}$ For example, when courts have dealt with other highly functional works like computer software, they have excluded from the infringement comparison those aspects of the plaintiffs' works that improved a program's efficiency. ${ }^{212}$ Accordingly, when decisionmakers are asked to compare garments like Varsity's to allegedly infringing copies like Star Athletica's, they should be instructed to ignore aspects of the plaintiff's work that contribute to its function, including dual-nature features like the ones discussed above. Doing so will help achieve Congress's goal of limiting copyright protection to func-

208 The Court refers to this argument but does not address it, because it does not deem partial functionality to bar protection. Star Athletica, 137 S. Ct. at 1013; see also Buccafusco \& Fromer, supra note 193, at 123.

209 See supra Sections II.B, II.C; see also Buccafusco \& Fromer, supra note 193, at 123.

210 See supra Section II.A.

211 See Buccafusco \& Lemley, supra note 6.

212 Comput. Assocs. Int'l, Inc. v. Altai, Inc., 982 F.2d 693, 709 (2d Cir. 1992); see also Peter S. Menell, Rise of the API Copyright Dead?: An Updated Epitaph for Copyright Protection of Network and Functional Features of Computer Software, 31 HARV. J.L. \& TECH. (forthcoming 2017); Pamela Samuelson, Functionality and Expression in Computer Programs: Refining the Tests of Software Copyright Infringement (UC Berkeley Pub. Law, Working Paper No. 2667740, 2015), http://papers.ssrn.com/sol3/papers.cfm?abstract_id=2667740. 
tional designs and will minimize costs to consumers and subsequent designers.

\section{Fashion's Function in Trademark Law}

Copyright law is not the only field of intellectual property law that is concerned with screening out functional aspects of product design. Both trademark law and design patent law also cast a wary eye toward functionality. Although the doctrines these regimes use to screen functionality differ from those employed by copyright law, their concerns are similar. ${ }^{213}$ Accordingly, we analyze how these two fields should respond to the particular issue of fashion design's dependent functionality, considering trademark law in this Part and design patent law in Part V.

Unlike copyright law, trademark law is not concerned with encouraging the creation of new aesthetic works. ${ }^{214}$ Instead, to promote fair competition and protect consumers, trademark law guards consumers from marketplace confusion by ensuring that certain symbols accurately reflect the source of goods. $^{215}$ If a pair of shoes has the distinctive Nike swoosh on it, consumers should be able to trust that the shoes are made by Nike. Trademark law covers more than just words or images that designate source, however. It can also be used to protect features of a product's design or packaging that identify its source. ${ }^{216}$ This is known as trade dress. Accordingly, the distinctive shape of a candy bar may indicate to consumers that it is made by Mars, Inc.

Trademark law is similar to copyright in at least one important respect: it also needs to be concerned about functionality. ${ }^{217}$ Just as features of a pictorial, graphic, or sculptural work can have utilitarian features, so too can a product's design or packaging. Moreover, allowing mark owners to protect the functional aspects of their designs can have anticompetitive effects as it does in copyright law. ${ }^{218}$ Like copyrights, trademarks do not undergo the substantial ex ante evaluation that patents do to ensure that they are new and nonobvious. Like copyrights, trademarks can, but need not, be registered to

213 Cf. Sarah Burstein, Faux Amis in Design Law, 105 Trademark Rep. 1455, 1455 (2015) ("There are . . f faux amis in U.S. design law-words that appear the same in the key legal regimes (design patent, trademark, and copyright) but which can have problematically different meanings. Consider, for example, the words 'functional' and 'ornamental.' These terms are used in all three regimes to describe limits on protectable subject matter. But they have different meanings in each." (footnote omitted)).

214 But cf. Jeanne C. Fromer, The Role of Creativity in Trademark Law, 86 Notre Dame L. REv. 1885 (2011) (arguing that trademark law encourages mark creators to devise ever more creative marks in some respects).

$2151 \mathrm{~J}$. Thomas McCarthy, McCarthy on Trademarks and Unfair Competition § 2:1 (4th ed. 2016); Mark P. McKenna, The Normative Foundations of Trademark Law, 82 NotrE DAme L. Rev. 1839, 1841 (2007).

216 See Wal-Mart Stores, Inc. v. Samara Bros., Inc., 529 U.S. 205 (2000); Two Pesos, Inc. v. Taco Cabana, Inc., 505 U.S. 763 (1992).

217 See Mark P. McKenna, (Dys)functionality, 48 Hous. L. Rev. 823 (2011).

218 Robert G. Bone, Trademark Functionality Reexamined, 7 J. LEgal Analysis 183 (2015); Buccafusco \& Lemley, supra note 6; McKenna, supra note 217. 
be protected. ${ }^{219}$ (However, among other requirements, trademarks cannot be confusingly similar to existing marks, ${ }^{220}$ ensuring that they must be "new" to some, but only to some, extent.) And even worse than copyrights, trademarks can last forever, so long as they remain in use in commerce. ${ }^{221}$ Accordingly, trademark law also applies a set of functionality screens to prevent claimants from using it as a means of obtaining backdoor patents. ${ }^{222}$

The rules of trademark law's functionality doctrines are complex, and there is little judicial or scholarly agreement about their precise contours. ${ }^{223}$ Without descending into a full analysis, we nonetheless show that our account of fashion's function also matters significantly to trademark law. In many cases, allowing trademark protection for aspects of garment design that affect the perception of the wearer's body will produce problematic anticompetitive effects.

\section{A. Trademark's Functionality Doctrine(s)}

To ensure that trademark law is not used to provide claimants with an undue competitive advantage, the law excludes functional trademarks and trade dress from protection. ${ }^{224}$ Trademark law enables owners to take advantage of the value of their reputations for producing high-quality products, but it seeks to prevent them from using trademarks to gain advantages unrelated to their reputation. ${ }^{225}$ This unfair advantage could result if the mark extended to cover useful product features that competitors were then prevented from producing. ${ }^{226}$ It could also occur if the mark extended to product features that consumers desired to purchase irrespective of their sourcesignifying characteristics. ${ }^{227}$ Trademark doctrine refers to the former of these concerns as "utilitarian functionality"228 and the latter, somewhat confusingly, as "aesthetic functionality." 229

219 See 15 U.S.C. $\$ \$ 1052,1114$ (2012).

$220 I d . \S 1052(\mathrm{~d})$.

221 Id. § 1051.

222 See Abercrombie \& Fitch Stores, Inc. v. Am. Eagle Outfitters, Inc., 280 F.3d 619, 640 (6th Cir. 2002) ("Protection of functional product features is the province of [not trademark law, but] patent law, which confers a monopoly over new product designs for a limited time only, after which competitors are free to copy at will.").

2231 MCCARTHY, supra note 215, $\$ 7: 81$ ("The notion of 'aesthetic functionality' is an unwarranted expansion of the utilitarian functionality policy, carrying it far outside the patent-related rationale that justifies the policy."); McKenna, supra note 217, at 824 ("[D] espite its potential power, the functionality doctrine is quite inconsistently applied.").

224 Buccafusco \& Lemley, supra note 6 (manuscript at 68).

225 McKenna, supra note 217, at 825.

226 In re Morton-Norwich Prods., Inc., 671 F.2d 1332, 1339 (C.C.P.A. 1982) (“[I]t is clear that courts in the past have considered the public policy involved in this area of the law as, not the right to slavishly copy articles . . but the need to copy those articles . . .." (emphasis omitted)).

227 Hughes, supra note 35, at 1240 .

$228 I d$. at 1238.

229 Id. at 1240. 
The Supreme Court case of TrafFix Devices, Inc. v. Marketing Displays, Inc. ${ }^{230}$ nicely illustrates the utilitarian functionality doctrine. In TrafFix, the plaintiff claimed trade dress protection for the dual-spring design of its windresistant road signs. The spring design had been claimed in an expired utility patent, and the plaintiff attempted to prevent others from using it as trade dress. According to the Court, "'[i]n general terms, a product feature is functional,' and cannot serve as a trademark, 'if it is essential to the use or purpose of the article or if it affects the cost or quality of the article.'"231 Here, the patent on the dual-spring design constituted strong evidence of such functionality. ${ }^{232}$ Additionally, the dual-spring design offered "a unique and useful mechanism to resist the force of the wind." 233 The design "is the reason the device works," 234 and thus it was barred from trademark protection to allow others adequate opportunity to compete.

Importantly, the TrafFix opinion distinguished the dual-spring design from "an arbitrary flourish" in the product's configuration. ${ }^{235}$ The Court explained, "[i] n a case where a manufacturer seeks to protect arbitrary, incidental, or ornamental aspects of features of a product found in the patent claims, such as arbitrary curves in the legs or an ornamental pattern painted on the springs, a different result might obtain." 236 Such features would have no effect on the product's function, and thus, allowing trademark protection over them would pose little risk to competition. Presumably, merely ornamental aspects of trade dress would not affect the cost or quality of the article. ${ }^{237}$

There might, however, be situations in which decorative or ornamental features of trade dress do unduly impinge upon healthy competition. For example, purchasers of farm equipment may desire that their equipment all be painted a particular shade of green. This may be because they think green is the most appropriate color for farm equipment or because they want all of their equipment to match, regardless of its source. In such a case, giving one party sole access to the shade of green would put other parties at a competitive disadvantage. ${ }^{238}$ Accordingly, courts have developed the doctrine of "aesthetic functionality" to prevent trade dress from imposing these costs.

Making out a case for aesthetic functionality is harder than it is for utilitarian functionality. As explained above, the latter can be proven by showing that the design feature affects the cost or quality of the article. Aesthetic

230532 U.S. 23 (2001).

231 Id. at 32 (alteration in original) (quoting Qualitex Co. v. Jacobson Prods. Co., 514

U.S. 159, 165 (1995)).

232 Id. at $29-30$.

$233 I d$. at 33.

234 Id. at 34.

235 Id.

236 Id. (emphasis added).

237 Id. at 33.

238 See Deere \& Co. v. Farmhand, Inc., 560 F. Supp. 85, 98 (S.D. Iowa 1982), aff'd, 721 F.2d 253 (8th Cir. 1983) (per curiam). 
functionality requires a more robust proof: to count as aesthetically functional, the design features must create a significant non-reputation-related advantage. ${ }^{239}$ Typically, this means that the product features amount to a competitive necessity and that other options are not nearly as good. ${ }^{240}$ Thus, if a particular color is important to distinguish different kinds or dosages of medication, courts should reject the use of that color as protectable trade dress. $^{241}$

\section{B. The Functionality of Trademarked Designs That Look Good On}

Whatever the doctrinal coherence of these two aspects of trade dress functionality law, it is clear that courts will inquire into the extent to which allowing protection will unduly restrict market competition. ${ }^{242}$ The safest trademarks and trade dress, then, will be those that are merely ornamental or are arbitrarily related to the product. ${ }^{243}$ From our analysis of garment design techniques in Part II, it should be clear that many aspects of clothing design will have some degree of trade dress functionality. In addition to the kinds of technical or mechanical functionality that trademark law already excludes, it should also recognize the ways in which trade dress can function to look good on. Copyright law treats features of garments that do not merely portray their own appearance as functional, as trademark law should with features that are not arbitrary and merely ornamental.

Features of clothing design that influence the way the wearer's body is perceived, such that they make him or her look thinner, bigger, taller, or curvier should be treated as bearing on the functionality inquiry in trade dress law. Such features should be treated as functional to the extent that they confer an unfair competitive advantage. A case from outside the garment design industry helpfully illustrates this point. In Brunswick Corp. v. British Seagull Ltd., ${ }^{244}$ Brunswick attempted to register use of the color black on outboard boat motors. ${ }^{245}$ The Federal Circuit affirmed the Trademark Trial and Appeal Board's refusal to register the trade dress on the ground

239 Qualitex Co. v. Jacobson Prods. Co., 514 U.S. 159, 165 (1995).

240 Id.

$241 I d$. at 170 ("The upshot is that, where a color serves a significant nontrademark function-whether to distinguish a heart pill from a digestive medicine or to satisfy the 'noble instinct for giving the right touch of beauty to common and necessary things,' courts will examine whether its use as a mark would permit one competitor (or a group) to interfere with legitimate (nontrademark-related) competition through actual or potential exclusive use of an important product ingredient." (citation omitted) (quoting G.K. Chesterton, Simplicity and Tolstoy 61 (1912))).

242 See TrafFix, 532 U.S. at 29 ("Trade dress protection must subsist with the recognition that in many instances there is no prohibition against copying goods and products. In general, unless an intellectual property right such as a patent or copyright protects an item, it will be subject to copying.").

$243 I d$. at 35.

24435 F.3d 1527 (Fed. Cir. 1994).

245 Id. at 1529. 
that it was functional. ${ }^{246}$ Here, functionality was grounded in part on the perception that "objects colored black appear smaller than they do when they are painted other lighter or brighter colors," and that purchasers often desire motors to look smaller. ${ }^{247}$ Because black changed people's perceptions of the motor's size and because this made black-colored motors more valuable in the market, granting exclusive rights to the color to a single firm would distort competition. Whether this sort of functionality is better labeled "utilitarian" or "aesthetic" is less important than the recognition that aspects of design can have these functional effects. ${ }^{248}$

We can readily imagine other scenarios in which a claimant's trade dress inappropriately influences the perception of objects. As with the motor, certain colors may influence how we perceive objects. ${ }^{249}$ High-visibility colors can be functional in the right context, and so too are other colors that affect people's perception of the size or shape of objects and bodies. Moreover, as mentioned above, incorporating certain two-dimensional patterns and shapes can also change how the wearer's body is perceived. ${ }^{250}$ Vertical stripes down the side of athletic pants-like the ones Adidas uses as a mark on its clothing ${ }^{251}$ - may make the wearer's legs look longer and leaner. Although the stripes might be source-signifying, they will also produce nonreputation-related advantages if people look sportier wearing them. ${ }^{252}$

In addition, three-dimensional aspects of garment design can also prove functional, just as they can in copyright law. Although savvy consumers may associate a particular dress design with, say, Stella McCartney, such as those shown on actress Kate Winslet in Figure 1, to the extent that it incorporates features that are not merely ornamental or arbitrary but instead influence how the wearer is perceived, the garment should not receive protection. ${ }^{253}$

$246 I d$.

247 British Seagull Ltd. v. Brunswick Corp., 28 U.S.P.Q.2d 1197, 1199 (T.T.A.B. 1993), overruled on other grounds by Cold War Museum, Inc. v. Cold War Air Museum, Inc., 586 F.3d 1352 (Fed. Cir. 2009).

248 Justin Hughes suggests that cases like these are better understood as "cognitive" or "perceptual" functionality because they involve taking advantage of humans' mental systems and preferences for certain shapes and features. Hughes, supra note 35, at 1252-53.

249 See id. (listing sources discussing color and perception).

250 See supra Part II.

251 See Adidas-Salomon AG v. Target Corp., No. CV-01-1582, 2002 WL 31971831, at *7-8 (D. Or. July 31, 2002).

252 This is different from other appliques that simply provide visual interest on a garment. See, e.g., Wal-Mart Stores, Inc. v. Samara Bros., Inc., 529 U.S. 205 (2000) (involving trade dress of this sort).

253 See Abercrombie \& Fitch Stores, Inc. v. Am. Eagle Outfitters, Inc., 280 F.3d 619, 624 (6th Cir. 2002) (“[T] he clothing designs A \& F seeks a monopoly on are functional as a matter of law, and therefore not protectable as trade dress."). In fact, the Sixth Circuit's approach to the functionality of clothing design in trademark law is even broader than the one we propose. The court seems to suggest that the combination of clothing elements to produce a certain image or aura is functional. See id. at 643. The court writes:

Use of these elements in combination with one another and with Abercrombie's trademarks on clothing bearing "primary color combinations . . . in connection 
The dresses depicted in Figure 3 clearly illustrate how to create a curvier, leaner look for the wearer. ${ }^{254}$ By contrast, Björk's famous swan dress, shown in Figure 8, may be sufficiently arbitrary that it could be a candidate for protection. ${ }^{255}$

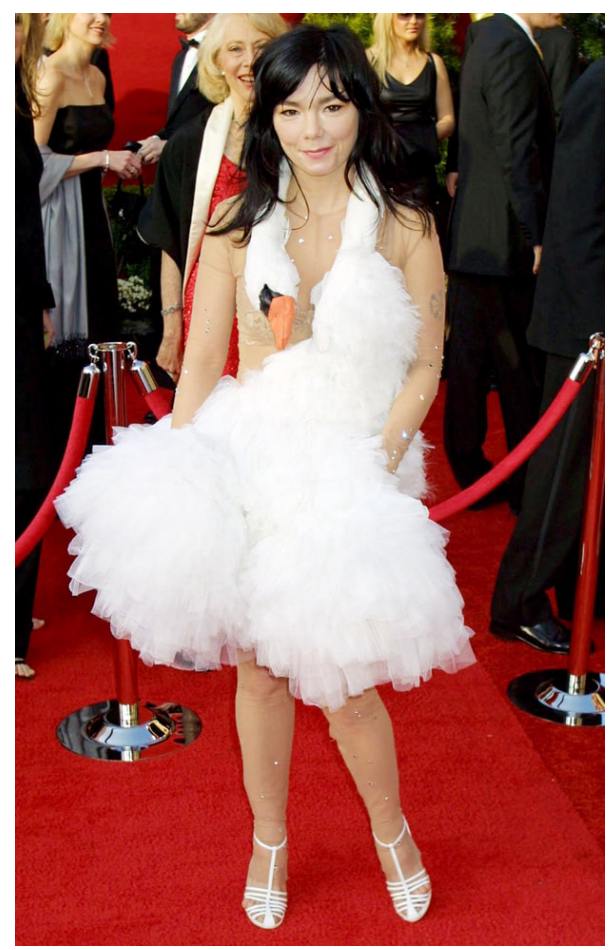

Figure 8: Björk's Swan Dress by Marjan Pejoski ${ }^{256}$

We do not take a position on whether any given design does or should meet the legal standard for exclusion in trade dress law. As explained above, trademark law has been somewhat more forgiving of certain kinds of func-

with solid, plaid and stripe designs" and made from "all natural cotton, wool and twill fabrics" creates reliable rugged and/or athletic casual clothing drawn from a consistent texture, design, and color palette. Were the law to grant Abercrombie protection of these features, the paucity of comparable alternative features that competitors could use to compete in the market for casual clothing would leave competitors at a significant non-reputational competitive disadvantage and would, therefore, prevent effective competition in the market.

Id.; see also Ann Bartow, Counterfeits, Copying and Class, 48 Hous. L. Rev. 707, 725 (2011). 254 See supra Section II.C.

255 See Timothy Mitchell, Björk's Once-Ridiculed Swan Dress Now Honored at MoMA, N.Y. Post (Mar. 15, 2015), http://nypost.com/2015/03/15/bjorks-once-ridiculed-swan-dressnow-displayed-at-moma.

256 Biggest Oscar Gaffes Ever!, Us WeEkLY (Feb. 18, 2013), http://www.usmagazine.com/ celebrity-news/pictures/biggest-oscar-gaffes-ever-2012242/21073. 
tionality than copyright law is. ${ }^{257}$ Setting the precise scope for trademark's functionality doctrine is beyond the scope of this Article. ${ }^{258}$ Nonetheless, it should be clear that the relationship between functionality and fashion in trademark law is significant.

\section{Fashion's Function in Design Patent Law}

"Function" plays yet a different role in design patent law than in copyright and trademark laws. Much like copyright and trademark laws, design patent law states that it protects ornamental aspects of qualifying designs and withholds protection from these designs' functional features. That said, design patent law seems to deem significantly fewer features as "functional" because of its different doctrinal definitions. Even if that means that design patent law might exclude fewer design features from protection than copyright and trademark laws, it still must analyze functionality in deciding protectability. When it comes to fashion designs covered by design patents, the law must therefore weigh in the balance design features that look good on as potentially functional and unprotectable. After describing how design patent law treats functional features, we discuss how design patent law might weigh dual-nature features in fashion that look good on.

\section{A. The Role of Functionality in Design Patent Law}

Creators of "any new, original and ornamental design for an article of manufacture" may obtain a design patent. ${ }^{259}$ Design patents provide protection from infringement for fifteen years from the date of patent grant. ${ }^{260}$ To get a design patent, a design's creator must apply to the Patent and Trademark Office, where the application will be examined for patentability. ${ }^{261}$ Unlike copyrights and trademarks, then, there must be some examination that a creation satisfies the design patentability criteria as a prerequisite to design patent protection. ${ }^{262}$

Design patent law does not treat the "ornamental[ity]" requirement as an affirmative condition that designs be aesthetically pleasing. ${ }^{263}$ Rather, the

257 For example, although vertical stripes down the leg of a pair of trousers are functional, this does not necessarily mean that trademark law must exclude a particular threestripe pattern from protection if there are sufficient options available to other creators.

258 Cf. Hughes, supra note 35 (proposing a test for cognitive functionality in trademark law).

25935 U.S.C. $\$ 171$ (2012). For a historical account of U.S. design patent law, see generally Jason J. Du Mont \& Mark D. Janis, The Origins of American Design Patent Protection, 88 IND. L.J. 837 (2013).

26035 U.S.C. $\$ \S 173,289$.

261 Id. $\$ \$ 111,112,171$; U.S. Patent \& Trademark Office, U.S. Dep't of Commerce, Manual of Patent Examining Procedure $\$ 1504$ (9th ed., rev. Nov. 2015); Matthew A. Smith, Design Patents 7 (preliminary draft) (Dec. 17, 2012), http://patentlyo.com/ media/docs/2012/12/2012-12-17_design_patents.pdf.

262 See Du Mont \& Janis, supra note 259, at 842.

263 Seiko Epson Corp. v. Nu-Kote Int'l, Inc., 190 F.3d 1360, 1368 (Fed. Cir. 1999). 
law has long seen this threshold requirement to mean that designs simply be "non-functional."264 The courts have furthermore not understood this requirement to mean that entire designs are necessarily rendered unprotectable for functionality; after all, the "article[s] of manufacture" that design patent law anticipates will be protected will typically have conventionally functional uses. ${ }^{265}$ Instead, courts understand the ornamentality/nonfunctionality requirement to signify that a "design patent only protects the novel, ornamental features of the patented design." 266

What "functional" means in the context of design patent law seems less stringent than in copyright and trademark law. A design feature is functional, and therefore unprotectable, only if the feature is " 'dictated by' the use or purpose of the article."267 By contrast, as the Federal Circuit has explained, " $[\mathrm{w}]$ hen there are several ways to achieve the function of an article of manufacture, the design of the article is more likely to serve a primarily ornamental purpose."268 A different design qualifies as an alternative way to achieve an article's function only if it provides "the same or similar functional capabilities" at a level of abstraction that is relatively concrete. ${ }^{269}$

264 Sмiтh, supra note 261, at 8; Jason J. Du Mont \& Mark D. Janis, Functionality in Design Protection Systems, 19 J. Intell. Prop. L. 261, 264 (2012) (noting, but criticizing, this definition of "ornamental"). "Ornamental" also subsumes a requirement that the design must be capable of "be[ing] perceived in [its] normal and intended uses." In re Webb, 916 F.2d 1553, 1557 (Fed. Cir. 1990). That is, it cannot always be concealed, or it must be capable of observation. Id.

265 Buccafusco \& Lemley, supra note 6 (manuscript at 2).

266 OddzOn Prods., Inc. v. Just Toys, Inc., 122 F.3d 1396, 1405 (Fed. Cir. 1997); accord Richardson v. Stanley Works, Inc., 597 F.3d 1288, 1293-94 (Fed. Cir. 2010).

267 L.A. Gear, Inc. v. Thom McAn Shoe Co., 988 F.2d 1117, 1123 (Fed. Cir. 1993) (first quoting In re Carletti, 328 F.2d 1020, 1022 (C.C.P.A. 1964); then citing Power Controls Corp. v. Hybrinetics, Inc., 806 F.2d 234, 238 (Fed. Cir. 1986)).

268 Id.; accord Ethicon Endo-Surgery, Inc. v. Covidien, Inc., 796 F.3d 1312, 1329-30 (Fed. Cir. 2015) (emphasizing the "availability of alternative designs as an important-if not dispositive-factor in evaluating the legal functionality of a claimed design”). Whether this test of availability of design alternatives is decisive or one factor in a multifactored test assessing functionality is not clear. See Burstein, supra note 213, at 1456 n.13.

269 Ethicon Endo-Surgery, 796 F.3d at 1331 (quoting Rosco, Inc. v. Mirror Lite Co., 304 F.3d 1373, 1378 (Fed. Cir. 2002)) (internal quotation marks omitted). In a recent Essay, Peter Menell and Daniel Yablon take issue with the account of design patent law's functionality doctrine that we, along with a number of other scholars, have articulated. Peter S. Menell \& Daniel Yablon, Essay, Star Athletica 's Fissure in the Intellectual Property Functionality Landscape, 166 U. PA. L. Rev. OnLine 137 (2017). They suggest that design patent law never covers the functional aspects of objects and that protection for functionality is reserved entirely for utility patent law. Perhaps due to the constraints of the Essay format, Menell and Yablon offer little in the way of legal support for this claim. To the contrary, design patent law cases consistently demonstrate that both the PTO and the courts are willing to include at least partially utilitarian features of designs within claim scope precisely because it understands features not to be dictated by the use or purpose of the article to be nonfunctional. See, e.g., Sport Dimension, Inc. v. Coleman Co., 820 F.3d 1316, 1318-19 (Fed. Cir. 2016); Apple Inc. v. Samsung Elecs. Co., 786 F.3d 983, 994, 996, 998-99 (Fed. Cir. 2015), rev'd on other grounds, 137 S. Ct. 429 (2016); see also Sarah Burstein, supra 
Courts assessing design patent infringement compare the design patent claim-a drawing depicting the patented design ${ }^{270}$ - overall to the defendant's accused design. ${ }^{271}$ Infringement is found when "an ordinary observer, giving such attention as a purchaser usually gives, [would find] two designs are substantially the same, if the resemblance is such as to deceive such an observer, inducing him to purchase one supposing it to be the other." 272 When construing a design patent's claim scope, care must be taken to "identify [only] the non-functional aspects of the design as shown in the patent." 273 As such, when the design has a mix of ornamental and functional features, courts are willing to construe the ornamental aspects verbally and precisely compared to what is otherwise a holistically visual claim construction. ${ }^{274}$ Moreover, the similarity requisite to finding infringement must be based on a protected design's ornamental features, and excluding its functional ones. ${ }^{275}$

Why exclude functional features or designs from design patent protection? The ornamentality requirement was inserted into the design patent

note 213; Michael Risch, Functionality and Graphical User Interface Design Patents, 17 STAN. TeCH. L. Rev. 53, 92-96 (2013).

Part of the confusion in this area may arise from slippage between design patent law's declared ban on functionality and the way that ban is actually applied. If a feature of a design is treated as "functional" by design patent law, it is to be excluded from the scope of the designer's claim. But a feature is treated as "functional" only in a relatively narrow class of cases: when it is dictated by function. This means that many design features that were not dictated by function but which were instead influenced by function or valued in part for their functionality would not be treated as functional and, thus, barred by design patent law. Of course, design patent law could define "functionality" more strictly to exclude more features influenced by function. But as the caselaw makes plain, it does not. More broadly, as we note above, which features qualify as "functional" in a particular intellectual property regime might differ from those that qualify in another such regime merely because each regime understands functionality in somewhat distinct ways. See supra text accompanying note 213. And each legal notion of "functionality" might not map precisely to our intuitive notions of what is functional.

270 See Jeanne C. Fromer \& Mark P. McKenna, Claiming Design 3 (unpublished manuscript in progress).

271 Sмiтh, supra note 261, at 29.

272 Gorham Co. v. White, 81 U.S. 511, 528 (1871).

273 OddzOn Prods., Inc. v. Just Toys, Inc., 122 F.3d 1396, 1405 (Fed. Cir. 1997) (citing Lee v. Dayton-Hudson Corp., 838 F.2d 1186, 1188 (Fed. Cir. 1988)).

274 See, e.g., Richardson v. Stanley Works, Inc., 597 F.3d 1288, 1293 (Fed. Cir. 2010); OddzOn Prods., 122 F.3d at 1400, 1405 (approving the district court's verbal claim construction- "a ball shaped like a football, with a slender, straight tailshaft projecting from the rear of the football. In addition, the . . Patent design has three fins symmetrically arranged around the tailshaft, each of which has a gentle curve up and outward which creates a fin with a larger surface area at the end furthest from the ball. The fins flare outwardly along the entire length of the tailshaft, with the front end of the fin extending slightly up along the side of the football so that the fins seemingly protrude from the inside of the football"-for a foam football-shaped ball with a tail and fin structure).

275 Richardson, 597 F.3d at 1295-96; OddzOn Prods., 122 F.3d at 1405. 
statute in 1902 at the request of the Patent Commissioner at the time. ${ }^{276}$ The commissioner indicated that the ornamentality requirement would separate design patents from utility patents on the one hand and copyrights on the other. With this requirement, design patent law would take:

its proper philosophical position in the field of intellectual production, having upon the one side of it the statute providing protection to mechanical constructions possessing utility of mechanical function, and upon the other side the copyright law, whereby objects of art are protected, reserving to itself the position of protecting objects of new and artistic quality pertaining, however, to commerce, but not justifying their existence upon functional utility. 277

The original judgment then seems to have been that design patents should cover the "ornamental" aspects of articles of manufacture, while utility patents should govern the "useful" aspects of those same articles. Each system would then be carefully calibrated for the encouragement and promotion of those aspects. And just as discussed above with regard to copyright and trademark laws, it would be detrimental to competition to allow backdoor utility patents through the design patent system. However, it is important to note that both design and utility patent laws-in contrast to either copyright or trademark law juxtaposed against utility patent law-have similar duration and examination rules. ${ }^{278}$ Perhaps the biggest difference, at least until recent changes, has been the much more limited scope of design patents as compared with the broader scope of utility patents. ${ }^{279}$ Yet since design patents have become easier to get in relation to utility patents and also broader in scope because of a distinct infringement standard, worries about design patents as backdoor utility patents linger. ${ }^{280}$

One uncertainty in design patent doctrine is how broadly or narrowly to construe "functionality." 281 For example, in one case involving a design patent for a football with an arrow-like tail, the design patent holder insisted that the tail is an ornamental feature because "it is not required for a tossing

276 Du Mont \& Janis, supra note 264, at 264-65 (citing sources).

277 S. ReP. No. 57-1139, at 3 (1902).

278 But cf. Smith, supra note 261, at 13 (justifying the more relaxed "functionality" bar in design patent law as connected to design patent's shorter duration).

279 Compare Unidynamics Corp. v. Automatic Prods. Int'l, Ltd., 157 F.3d 1311, 1323 (Fed. Cir. 1998) (Rich, J.) ("[D] esign patents have almost no scope beyond the drawings.”), abrogated by Egyptian Goddess, Inc. v. Swisa, Inc., 543 F.3d 665 (Fed. Cir. 2008) (en banc), with Mark P. McKenna \& Katherine J. Strandburg, Progress and Competition in Design, 17 Stan. Tech. L. Rev. 1, 2 (2013) (discussing how the relative ease of obtaining design patents and their growing scope has made them more popular recently). Design patent scope has also become broader since the Federal Circuit eliminated the point-of-novelty test in Egyptian Goddess, Inc. v. Swisa, Inc., 543 F.3d 665, 678 (Fed. Cir. 2008) (en banc). See generally Mark A. Lemley, Point of Novelty, 105 Nw. U. L. Rev. 1253 (2011).

280 See supra note 279.

281 See Smith, supra note 261, at 41 (observing that articulating when designs have the "same function" for purposes of infringement is "a slippery concept"). 
ball," 282 imputing that relatively broad function to the design. The Federal Circuit thought the function was narrower-because "the ball in question is specifically designed to be thrown like a football, yet travel farther than a traditional foam football"-yet not so narrow that "these functional characteristics ... invalidate the design patent, [rather than] merely limit the scope of the protected subject matter." 283

To take another example closer to this Article's subject matter of fashion, consider a litigated sneaker design. The defendant in the case argued that all features of the design were functional and therefore unprotectable:

$[\mathrm{T}]$ he delta wing provides support for the foot and reinforces the shoelace eyelets; the mesh on the side of the shoe also provides support; the moustache at the back of the shoe provides cushioning for the Achilles tendon and reinforcement for the rear of the shoe; and the position of each of these elements on the shoe is due to its function. ${ }^{284}$

The Federal Circuit rejected the defendant's characterization as legally inapt, indicating that the entire claimed design collectively must be dictated by function, not that claimed features individually are functional. ${ }^{285}$

In sum, functional and nonfunctional features of designs must be sorted under design patent law. Nonfunctional features may be protected, whereas functional features may not. That said, courts have made it harder in design patent law for design features to count as functional, thereby disqualifying them from design patent protection. We now turn to how our understanding of fashion's function can implicate these determinations in design patent law.

\section{B. Patented Designs That Look Good On}

In this Section, we discuss how the "looking good on" function of fashion design can play a role in which aspects of fashion designs are protectable under design patent law. There have been long-recognized concerns with turning to design patent protection for fashion designs generally. To take one practical worry, unlike copyright and trademark, which can vest automatically, it takes longer to obtain a design patent. On average, design patents issue about twenty months from filing. ${ }^{286}$ By the time a design patent issues,

282 OddzOn Prods., Inc. v. Just Toys, Inc., 122 F.3d 1396, 1406 (Fed. Cir. 1997) (internal quotation marks omitted).

283 Id.

284 L.A. Gear, Inc. v. Thom McAn Shoe Co., 988 F.2d 1117, 1123 (Fed. Cir. 1993).

285 Id.; accord Ethicon Endo-Surgery, Inc. v. Covidien, Inc., 796 F.3d 1312, 1329 (Fed. Cir. 2015). This holistic approach to functionality seems to conflict with the element-byelement approach of assessing ornamentality as nonfunctionality; see supra text accompanying notes 263-266; see also Du Mont \& Janis, supra note 264, at 271-81 (highlighting this doctrinal discrepancy).

286 Robert C. MacKichan III, Despite Increased Hiring, Design Patent Application Backlog Builds, Prosecution First Blog (Mar. 7, 2016), https://prosecutionfirstblog.com/2016/ 03/07/despite-increased-hiring-design-patent-application-backlog-builds. 
the fashion cycle has typically long since moved on, potentially rendering the protection meaningless for fashion designs. ${ }^{287}$

Nonetheless, seeking and asserting design patent protection for fashion designs has become increasingly popular. ${ }^{288}$ Fashion design companies can succeed with design patents through speed in filing, combined with luck or foresight as to which of their designs will transcend the typical fashion cycle. ${ }^{289}$ Pertinently, there might be some fashion designs whose popularity will outlast the time until design patent grant. As one-perhaps extremeexample, consider the pricey Hermès Birkin handbag whose value has, according to one study, "outpaced both the S\&P 500 and the price of gold in the last 35 years." 290 Filing a design patent on this handbag design would surely have been a smart investment by Hermès. Additionally, as trademark

287 See Beebe, supra note 38, at 864; Christina Phillips, Note, The Real Cinderella Story: Protecting the Inherent Artistry of the Glass Slipper Using Industrial Design, 48 VAL. U. L. REv. 1177, 1216-17 (2014); Rocky Schmidt, Comment, Designer Law: Fashioning a Remedy for Design Piracy, 30 UCLA L. REv. 861, 868 (1983). Another concern is whether fashion designs can be nonobvious, even when they are commercially successful. See, e.g., Belding Heminway Co. v. Future Fashions, Inc., 143 F.2d 216, 217 (2d Cir. 1944) (per curiam) ("Such fugitive popularity as fashions in dress are apt to enjoy, are often the result of caprice; it is impossible for even the most adept students of the market to tell in advance which ones will succeed, or whether any one will. Surely in such a setting success is a poor test of aesthetic achievement. In the absence of evidence that the design, which happened to hit the public fancy, was a wide departure from the past, we should not feel justified in holding the patent valid merely because of its grant.”); White v. Leanore Frocks, Inc., 120 F.2d 113, 114-15 (2d Cir. 1941) (per curiam) (expressing skepticism that "valid design patents can be procured in [large enough] number as to answer their demand"); McKenna \& Strandburg, supra note 279, at 4 (asking whether a nonobviousness requirement is meaningful at all for designs). For a broad look at concerns with design patents, see Sarah Burstein, Moving Beyond the Standard Criticisms of Design Patents, 17 Stan. Tech. L. REV. 305 (2013).

288 See, e.g., Sarah Burstein, Design Patent Myths-You Can Only Get Design Patents for Applied Ornaments, Faculty Lounge (Oct. 21, 2013, 8:12 AM), http://www.thefaculty lounge.org/2013/10/ornaments.html; Currently Trending in Fashion: Design Patents, FAsHION LAW (June 23, 2016), http://www.thefashionlaw.com/home/currently-trending-infashion-design-patents; Clare O'Connor, Fashion's 'Apple v. Samsung': Spanx Patent War Could Change How Brands Fight Copycats, Forbes (Apr. 10, 2013), http://www.forbes.com/ sites/clareoconnor/2013/04/10/fashions-apple-vs-samsung-spanx-patent-war-couldchange-how-brands-fight-copycats.

289 Cf. Elizabeth Ferrill \& Tina Tanhehco, Protecting the Material World: The Role of Design Patents in the Fashion Industry, 12 N.C. J.L. \& TECH. 251, 292 (2011) ("Choosing to apply for only a single design patent on one product of many is unlikely to provide long-term benefit to a designer, primarily because that designer is probably not lucky enough to choose the 'it' product of the season. The wiser strategy is for a designer to commit to patenting several designs. As the designer becomes more experienced at filing design patent applications, she will improve her skills at identifying those parts of a particular design in need of protection.").

290 Tara John, Why the Hermès Birkin Bag Is a Better Investment than Gold, Time (Jan. 15, 2016), http://time.com/4182246/hermes-birkin-bag-investment-gold (noting that "the annual return on a Birkin was $14.2 \%$, compared to the S\&P average of $8.7 \%$ a year and gold's $-1.5 \%$ "). 
law's strict understanding of the functionality bar has made it harder and harder to protect certain design features, there has been a greater shift toward the design patent regime, with its comparatively laxer functionality restrictions. $^{291}$ A sampling of recent design patents issued for fashion designs includes a dinosaur-covered infant body suit, ${ }^{292}$ a high-fashion (and trendy) lace-up shoe, ${ }^{293}$ and a strapless dress design. ${ }^{294}$

With a newly enhanced focus on design patents for fashion designs will come a need to separate ornamental design features from functional ones in fashion designs. ${ }^{295}$ Consider design patent infringement litigation filed by athletic and yoga apparel company Lululemon Athletica against apparel company Calvin Klein in 2012.296 Lululemon accused Calvin Klein of infringing its design patents on its popular “Astro Pant." Figure 9 depicts two figures of the design patent claim drawing for the Lululemon yoga pant. Figure 10 depicts on the left Lululemon's Astro Pant, a commercialization of its design patent, and on the right Calvin Klein's allegedly infringing and cheaper pant. Figure 11 shows a back view of the Lululemon Astro Pant.
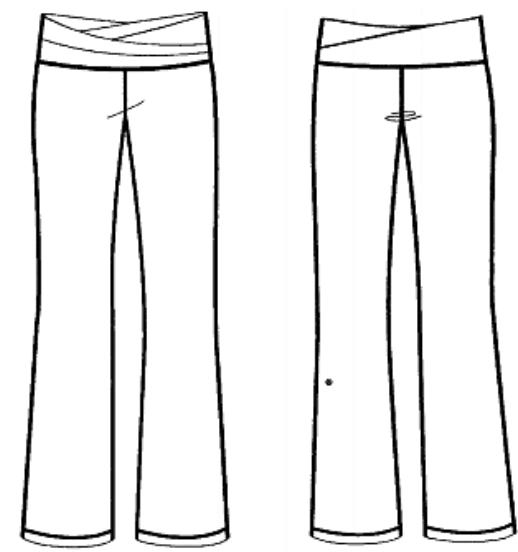

Figure 9: Litigated Lululemon Pants 297

291 See Sмiтh, supra note 261, at 13; McKenna, supra note 217.

292 U.S. Patent No. D760,998 (filed July 10, 2013).

293 U.S. Patent No. D750,359 (filed June 25, 2015) (claiming what has been sold as the Aquazzura Christy shoe).

294 U.S. Patent No. D698,120 (filed Feb. 13, 2012).

295 See supra Part I.

296 Ashby Jones, Downward Docket: The Yoga Pants War, Wall St. J. (Sept. 11, 2012), http://www.wsj.com/articles/SB10000872396390443696604577645891750143350.

297 U.S. Patent No. D645,644 (filed Apr. 16, 2010). 


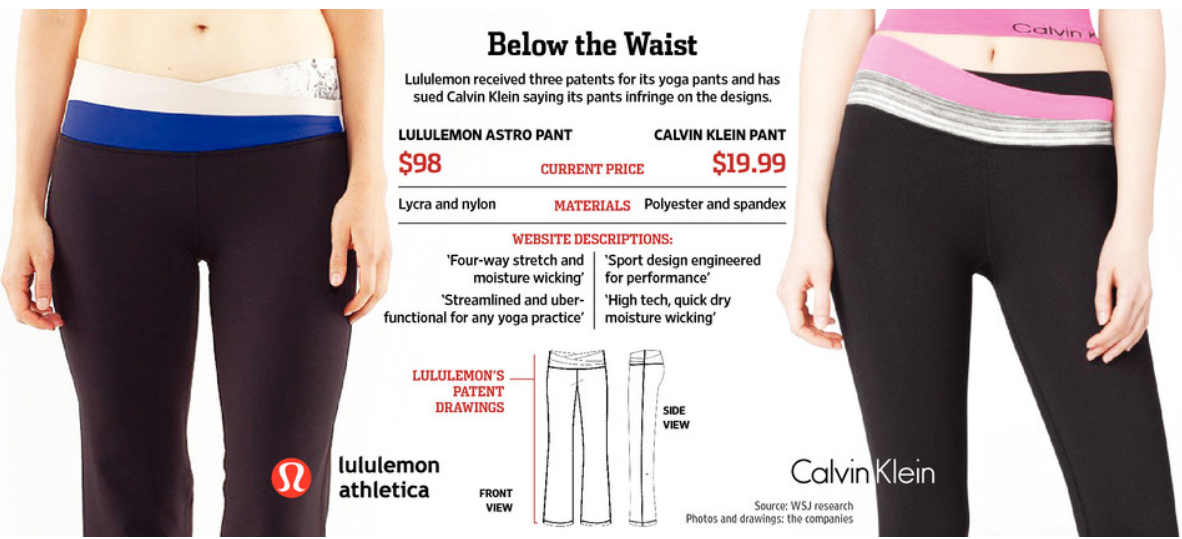

Figure 10: Comparison of Lululemon and Calvin Klein Yoga Pants 298

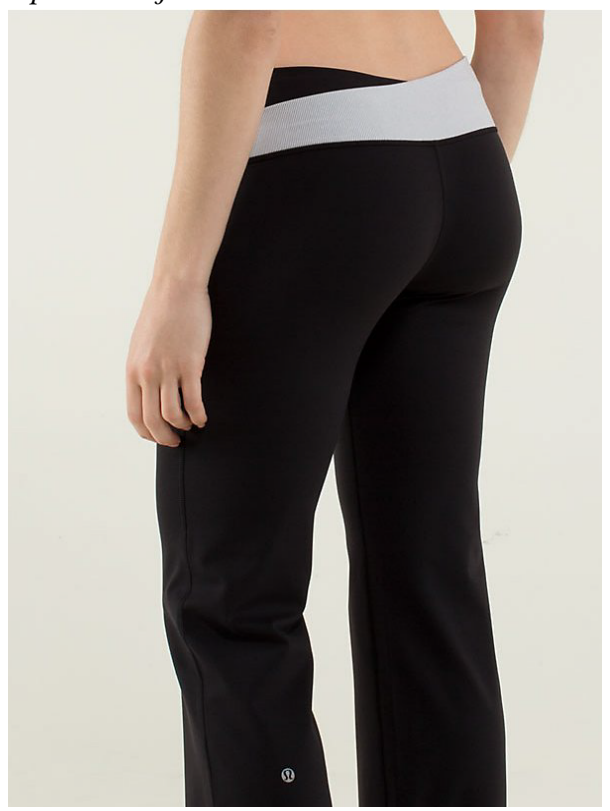

Figure 11: Back view of Lululemon Astro Pant 299

Though the case settled quickly before any substantive rulings on Lululemon's design patents or the infringement claim, ${ }^{300}$ it serves as a helpful illustration of how fashion's function can have an impact on distinguishing ornamental from functional features in design patent law. Lululemon

298 Jones, supra note 296.

299 Lululemon Astro Pant (Tall) * Full-On Luon, Lulu Fanatics, https://www.lulufanatics .com/item/16338/lululemon-astro-pant-tall-full-on-luon-black-wee-stripe-white-heatheredmedium-grey-white (last visited Oct. 17, 2017).

300 Ben Fox Rubin, Lululemon, Calvin Klein Agree to Settle Yoga-Pants Suit, Wall St. J. (Nov. 20, 2012), http://www.wsj.com/articles/SB100014241278873248517045781315014 25509018. 
yoga pants, including the claimed design, have become renowned for their design features that flatter a wearer's body. One account, for example, compares Lululemon's yoga pants to other brands' cheaper pants, pronouncing Lululemon's worth the higher price because Lululemon's waistband has "this incredible high rise panel that comes right up to your natural waist . . . and holds everything in. I swear, it takes [five] pounds off." ${ }^{01}$ Another review states that the significantly higher cost of Lululemon pants is fully justified by "a seam across the top of the butt that makes my ass look better than it does in any other running pants, ever."302 Taking these accounts at face value, then, the waistband and back seam are both seemingly ornamental features that also are functional, in that they change the appearance of the wearer.

Design patent law ought to take account of these dual-nature design features in fashion. That is, the law must sort out how to characterize these features: as ornamental or not ornamental. Design patent law must decide whether these features that function to change the appearance of the wearer rather than merely to look attractive in their own right are well accounted for in the calibrations of design patent law or are better addressed by utility patent law. ${ }^{303}$

Design patent law must also develop a better account of the level of abstraction at which to assess function. ${ }^{304}$ Is the function of the yoga pant in part to slim and to enhance the body's curves? If so, with regard to slimming, is the relevant function to slim generally, which can be accomplished in a myriad of ways, or to slim with a well-designed waistband? Similarly, with regard to enhancing the curves, is the relevant function to enhance curves generally or to enhance the backside curve through use of a well-placed seam? Depending on the level of abstraction, the pant's slimming and curveenhancing features might or might not be dictated by function.

As with our discussion of trademark law, we do not here offer a complete analysis about the best rules for design patent law's functionality screen. Determining the optimal scope for any of these fields involves a sophisticated inquiry into a variety of different costs and benefits, including the need for incentives to create and commercialize new designs, the existence of administration and adjudication costs, and the effects of protection on competition. ${ }^{305}$ Nonetheless, our contribution here is significant: To the extent that design patent law-or the other non-utility patent IP regimes-ignores fash-

301 Jo-Lynne Shane, Fashion/Fitness Friday :: Lululemon Review, Jo-Lynne Shane (Jan. 11, 2013), http://www.jolynneshane.com/lululemon-review.html (noting also how the pants are technologically functional by keeping her "completely comfortable in [thirty] degree weather, even with the wind blowing”).

302 Sarah Mesle, The Unbearable Awesomeness of Lululemon Pants, AvidLy (June 4, 2013), http:/ / avidly.lareviewofbooks.org/2013/06/04/the-unbearable-awesomeness-of-lululem on-pants (indicating how others praise these pants for their durability over time).

303 See supra text accompanying notes 276-280.

304 See supra text accompanying notes 281-285.

305 See Buccafusco \& Lemley, supra note 6 (manuscript at 1). 
ion's function it risks imposing substantial limits on competition, stifling innovation, and increasing costs to consumers.

\section{CONCLUSION}

The account of fashion's function that we develop in this Article clarifies how intellectual property law should treat fashion design. It recognizes an important way in which designs are functional-when they affect how wearers' bodies are perceived. This is not simply an issue with fashion design, however. As fashion designer and businesswoman Coco Chanel famously said, "Fashion is not something that exists in dresses only. Fashion is in the sky, in the street. Fashion has to do with the ideas, the way we live, what is happening."306 Looking beyond fashion, many visual media can affect the ways that we perceive objects. Trompe l'oeil painting and camouflage techniques have this effect. The same is true of chemical or physical processes for developing pigments, such as Vantablack, a carbon nanotube surface coating that produces the sensation of perfect blackness. ${ }^{307}$ Attempts to gain intellectual property protection for any of these techniques, unless through the patent system, should be met with intense skepticism.

306 See Rachel Dixon, Coco Before Chanel: 'She Was Claiming Freedom Through Her Designs,' GuARDian (July 31, 2009), https://www.theguardian.com/lifeandstyle/2009/jul/31/cocobefore-chanel.

307 See Elizabeth Blair, Some Artists Are Seeing Red over a New 'Black, 'NPR (Mar. 3, 2016), http://www.npr.org/sections/thetwo-way/2016/03/03/469082803/some-artists-are-see ing-red-over-a-new-black. 